\title{
The Cristalino IOCG deposit: an example of multi-stage events of hydrothermal alteration and copper mineralization
}

\author{
Gustavo Souza Craveiro ${ }^{*}$ (D), Roberto Perez Xavier² (D), Raimundo Netuno Nobre Villas' (D)
}

\begin{abstract}
The Cristalino deposit is located $40 \mathrm{~km}$ east of Sossego mine, Carajás. The orebody lies along a NW-SE-striking shear zone and is mainly hosted by the Neoarchean bi-modal volcanics of the Grão Pará Group. Field work and petrographic data seconded by SEM-EDS analysis allowed recognizing an early sodic metasomatism that was followed by calcic-ferric, potassic and propylitic alterations, and finally by carbonatization. The volcanic rocks were altered under deformation regimes that changed from ductile-brittle to brittle. The deposit resulted from two mineralizing stages. The early stage took place at a greater depth and produced an ore association composed chiefly of chalcopyrite, pyrite, and magnetite as disseminations, breccia and veins particularly in Ca-Fe altered rocks. The later stage occurred at a shallower depth and formed a practically magnetite-free ore association, consisting essentially of chalcopyrite \pm pyrite \pm hematite in breccias and veins generated mostly during the potassic alteration. These ore associations indicate that the hydrothermal system evolved with temperature decrease and increase in $\mathrm{fO}_{2} \mathrm{Cu} / \mathrm{Fe}$ ratio and sulfur activity. Cristalino is conceived as a multi-stage IOCG deposit similar to others lying in the Carajás E-W corridor of IOCG systems.
\end{abstract}

KEYWORDS: Iron oxide-copper-gold; Metallogenesis; Hydrothermal system; Neoarchean; Carajás Province.

\section{INTRODUCTION}

Copper reserves in Brazil are in the order of $11 \mathrm{Mt}(1.5 \%$ of the world) (Xavier et al. 2017), ca. 85\% of which are concentrated in copper systems of the Carajás Province, an Archean crustal segment in the southeastern Amazon Craton, northern Brazil. This province is divided into two tectonic domains: Rio Maria Domain in the south, and Carajás Domain (CD) in the north (Fig. 1A).

A variety of copper deposits occur in the $\mathrm{CD}$ and may be broadly divided into two systems (Xavier et al. 2017):

1. iron oxide-copper-gold (IOCG), the most economically important deposits;

2. copper-polymetallic.

These copper systems are structurally controlled by regional-scale WNW-ESE-striking brittle-ductile shear zones (e.g., Carajás and Cinzento in the northern sector, and Canaã in the southern sector), particularly close to the contact between the basement and supracrustal units of the CD (Xavier et al. 2012; Fig. 1B).

\footnotetext{
${ }^{1}$ Programa de Pós-Graduação em Geologia e Geoquímica, Instituto de Geociências, Universidade Federal do Pará - Belém (PA), Brazil. E-mails: craveiro@ufpa.br, netuno@ufpa.br

${ }^{2}$ Departamento de Geologia e Recursos Naturais, Instituto de Geociências, Universidade Estadual de Campinas - Campinas (SP), Brazil. E-mail: xavier@ige.unicamp.br

${ }^{*}$ Corresponding author.
}

(C) 2019 The autors. This is an open access article distributed under the terms of the Creative Commons license.
Geochronological data reveal that the Carajás IOCG systems were emplaced during multiple hydrothermal episodes within the Neoarchean and Paleoproterozoic, with ore-forming events having occurred at:

1. $2.72-2.68 \mathrm{Ga}$, represented by the Sequeirinho - Pista ore bodies, Sossego deposit (245 Mt @ $1.1 \% \mathrm{Cu}, 0.28 \mathrm{~g} / \mathrm{t} \mathrm{Au}$ ), and its satellite deposits, including Bacuri, Bacaba, Castanha, Visconde and Pedra Branca, all in the southern sector (Moreto et al. 2015a, 2015b);

2. $2.60-2.53 \mathrm{Ga}$ recorded at the Salobo (1.11 Gt at $0.69 \%$ $\mathrm{Cu}, 0.43 \mathrm{~g} / \mathrm{t} \mathrm{Au}$ ), Igarapé Bahia/Alemão (219 Mt @ $1.4 \% \mathrm{Cu}, 0.86 \mathrm{~g} / \mathrm{t} \mathrm{Au}$ ) and Grota Funda deposits in the northern sector (Réquia et al. 2003, Tallarico et al. 2005, Hunger 2017);

3. $1.90-1.88 \mathrm{Ga}$, having as examples the Sossego-Curral ore bodies (Sossego deposit) and Alvo 118 deposit (170 Mt (a) $1.0 \% \mathrm{Cu}, 0.3 \mathrm{~g} / \mathrm{t} \mathrm{Au}$ ), also in the southern sector of the CD (Grainger et al. 2008, Moreto et al. 2015a).

Mesoarchean basement gneisses/granitoids and Neoarchean metavolcano-sedimentary units of the Itacaiúnas Supergroup as well as gabbros/diorites, quartz-feldspar porphyries, and A2-type anorogenic granites may be hosts to the IOCG systems (Xavier et al. 2012).

The Neoarchean $2.72-2.68$ and $2.60-2.53$ Ga IOCG systems were generally emplaced at deeper crustal levels and display distal $\mathrm{Na}$-Ca alteration (albite-scapolite-hastingsite-actinolite-epidote) followed by variable combinations of more proximal and structurally-controlled calcic-ferric (actinolite-magnetite-apatite), iron-rich (almandine-grunerite-tourmaline-magnetite), potassic-ferric (K-feldspar and 
biotite-magnetite), and/or chlorite-epidote-carbonate alteration types (Xavier et al. 2017). Copper ore zones are represented by chalcopyrite-pyrite-siegenite-magnetite-actinolite-chlorite-apatite-allanite breccias in the southern sector (e.g., Sequeirinho - Pista ore bodies, Visconde and Pedra Branca deposits). In the northern sector, copper ore zones include massive magnetite lenses containing disseminated bornite-chalcocite (e.g., Salobo), magnetite-chalcopyrite-actinolite breccias (e.g., Igarapé Bahia/Alemão, Grota Funda), chalcopyrite-bornite-magnetite veins, stockworks and breccias (e.g., Furnas) or chalcopyrite disseminations along the mylonitic foliation (e.g., GT46).
Compared to the Neoarchean examples, the Paleoproterozoic IOCG systems represent hydrothermal systems developed at shallower crustal levels, controlled predominantly by brittle structures. These systems are generally characterized by absent or poorly developed sodic-calcic or calcic-ferric alteration, but commonly display strong and pervasive potassic-ferric alteration (K-feldspar and biotite with magnetite) (Tallarico 2003, Torresi et al. 2012, Xavier et al. 2017), normally overprinted by extensive zones dominated by chlorite, epidote, calcite or sericite that host the copper-gold ore. The ore forms breccia (Sossego-Curral) and vein systems (Alvo 118) containing quartz, calcite, actinolite, magnetite/hematite, apatite, and

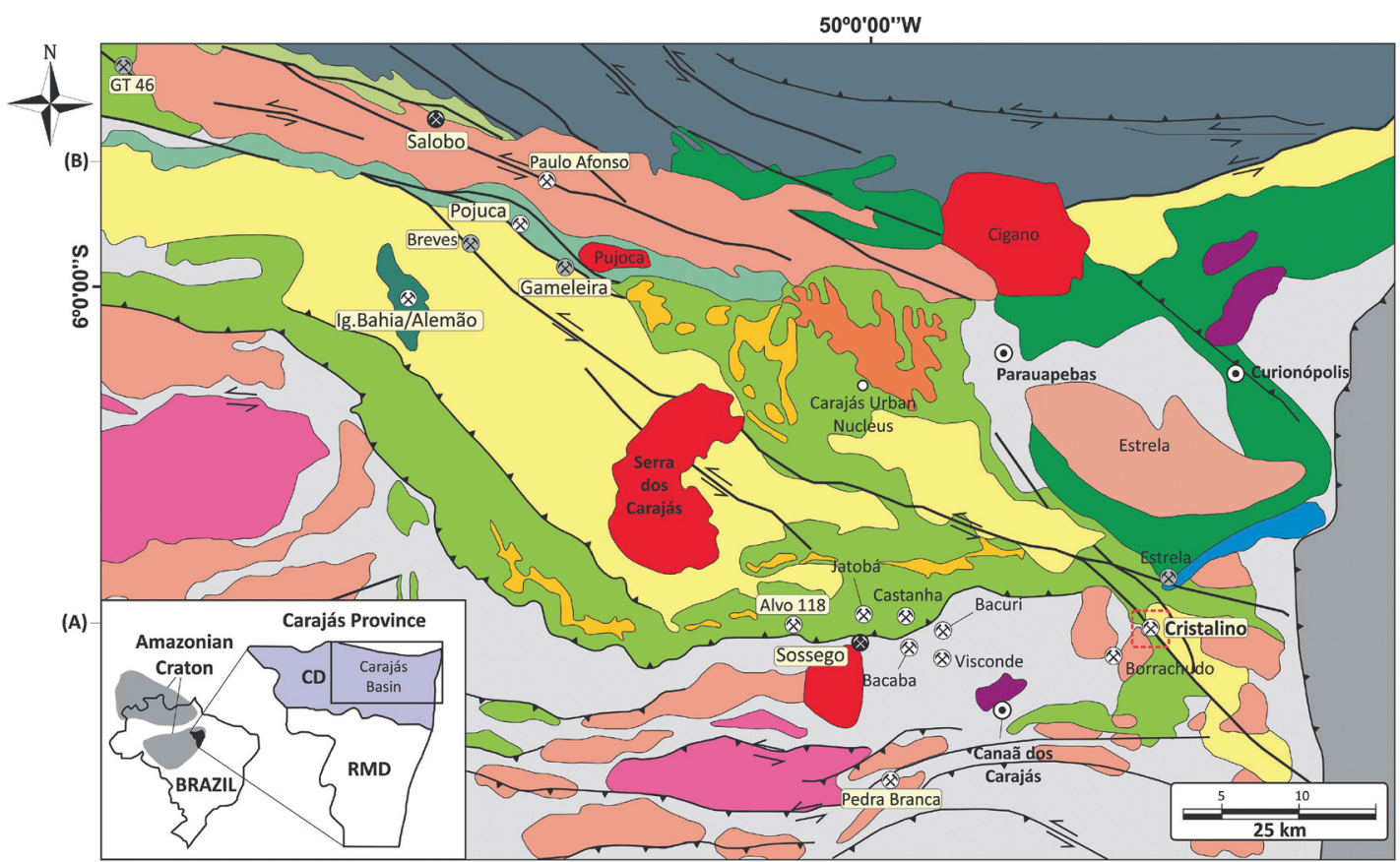

\section{CENOZOIC}

Lateritic Cover

\section{NEOPROTEROZOIC}

Araguaia Belt

\section{PALEOPROTEROZOIC}

Bacajá Domain

\section{CARAJÁS DOMAIN}

A-type Granites (1.88 Ga)

\section{NEOARCHEAN}

Águas Claras Formation/ Rio Fresco Group (ca. 2.7 Ga)

Santa Inês Gabbro

Mafic-ultramafic layered intrusions (2.76 Ga)

Subalkaline Granites (2.76 to $2.73 \mathrm{Ga}$ )

CONVENTIONS

ITACAIÚNAS SUPERGROUP

(2.73 to $2.76 \mathrm{Ga}$ )

$\square$ Igarapé Pojuca Group $(2.73 \mathrm{Ga})$ Igarapé Bahia Group (2.74 - $2.77 \mathrm{Ga})$

\section{Grão Pará Group}

Carajás Fm. (2.74 Ga) Parauapebas Fm. (2.75 Ga)

\section{Igarapé Salobo Group}

Rio Novo Group (>2.76 Ga)

\section{MESOARCHEAN}

Xingu Complex (2.85 - 2.97 Ga)

Pium Complex (3.00 Ga)

\section{Contact}

_. Thrust fault

- Fault

Transpressional shear zone

(*) IOCG deposit

(ख) Copper-polymetallic deposit

Q Mine (IOCG deposit)

- City

O Village

Cristalino IOCG deposit area

RMD: Rio Maria domain.

Figure 1. (A) Location of the Carajás Domain (CD) in the Amazon Craton (Santos et al. 2000); (B) geological map of the Carajás Domain showing the location of important iron oxide-copper-gold (IOCG) and Cu-polymetallic systems (modified from Vasquez et al. 2008). The inset area represents the site of the Cristalino IOCG deposit. 
sulfides (chalcopyrite, pyrite, siegenite). In both Neoarchean and Paleoproterozoic IOCG systems, the $\mathrm{Fe}-\mathrm{Cu}-\mathrm{Au}$ association is generally accompanied by variable concentrations of P-LREE-U-Ni-Co-Pd.

The Cristalino deposit is located about $40 \mathrm{~km}$ east of Sossego mine and immediately south of the Estrela copper-polymetallic deposit at the eastern termination of Carajás fault, in the Serra do Rabo region (Fig. 1B). It is a world-class Cu-Au (379 Mt@0.66\% Cu, 0.3 g/t Au; Pinto 2012)deposit of the southern sector of the $\mathrm{CD}$ that probably belongs to the $2.72-2.68 \mathrm{Ga}$ IOCG group $(2719 \pm 36 \mathrm{Ma}, \mathrm{Pb}-\mathrm{Pb}$ in sulfide, Soares et al.2001). Despite its economic importance and possibility to become a mine in the near future, none of the few available studies (Huhn et al. 1999, Soares et al. 2001, Ribeiro et al. 2009, among others) have fully investigated the temporal evolution of the Cristalino hydrothermal system and associated copper mineralization.

The main goal of this work was to characterize the host rocks and the alteration zones of the Cristalino deposit, as well as to present a consistent paragenetic sequence of the hydrothermal minerals resulting from the alteration processes. In addition, it aims to point out possible evidence of overlapping of different mineralization styles at Cristalino, as described recently in other IOCG systems of the CD (Moreto et al. 2015a, 2015b, Melo et al. 2017, Xavier et al. 2017), with implications on physico-chemical variations of the fluid regime and copper deposition during the evolution of the hydrothermal system.

\section{GEOLOGICAL SETTING OF THE CARAJÁS DOMAIN}

The CD is made up of Mesoarchean $(3.08-2.83 \mathrm{Ga})$ basement rocks, with TTG-like gneisses-migmatites, orthogranulites and calc-alkaline granitoids overlain by Neoarchean metavolcano-sedimentary sequences of the Rio Novo Group $(>2.76 \mathrm{Ga})$ and Itacaiúnas Supergroup $(2.76-2.73 \mathrm{Ga})$ as well as metasiliciclastic rocks of the Águas Claras Formation (> 2.65 Ga) (Fig. 1B; Vasquez et al. 2008).

The Rio Novo Group is a mafic/ultramafic volcano-sedimentary sequence with banded iron formations (BIF) and metapelites (Araújo \& Maia 1991, Oliveira 1994, Vasquez et al. 2008) which outcrops in the Serra Pelada region. It has a minimum age of 2,763 $\pm 7 \mathrm{Ma}$, the dating of the intrusive Luanga mafic-ultramafic and the Estrela granitic complexes (Machado et al. 1991, Barros et al. 2001).

The Itacaiúnas Supergroup encompasses the following groups: Igarapé Salobo, Igarapé Pojuca, Grão Pará and Igarapé Bahia. Their lower units are dominantly composed of bi-modal volcanic rocks, whereas intermediate units comprise thick layers of BIF. Dominantly of sedimentary nature, the upper units are made up of metasiltstones, metargilites and BIF intercalated with metabasalts (Docegeo 1988, Soares et al. 1999, Ronzê et al. 2000, Lindenmayer et al. 2001, Vasquez et al. 2008).

Mafic-ultramafic layered igneous intrusions crosscut the basement rocks and the Itacaiúnas Supergroup, being represented by the Serra Leste and the Cateté Intrusive suites. They consist of clusters of elongated bodies mineralized with PGE-, Cr- or Ni (Macambira \& Vale 1997, Mansur \& Ferreira Filho 2016, Siepierski 2016). As part of the Serra Leste Suite, the chromite-bearing Luanga and Lago Grande complexes have been dated at 2,763 $\pm 7 \mathrm{Ma}$ (Machado et al. 1991 ) and 2,722 $\pm 53 \mathrm{Ma}$ (Teixeira et al. 2015), respectively, overlapping the Neoarchean bimodal magmatism of the Grão Pará Group.

High potassium subalkaline granites, namely the Estrela Complex, Serra do Rabo, Igarapé Gelado and Old Salobo bodies, have been emplaced in the Carajás basin rocks (Feio et al. 2013) with emplacement ages spanning from 2,763 to $2,573 \mathrm{Ma}$.

Archean sedimentary covers include the marine coastal Águas Claras Formation, which overlies unconformably the Itacaiúnas Supergroup (Nogueira et al. 1995), and Rio Fresco Formation, which overlies the Rio Novo Group and hosts the epigenetic Au-PGE Serra Pelada deposit (Grainger et al. 2008). Their deposition age is uncertain, ranging from 2.70 to $2.30 \mathrm{Ga}$, according to $\mathrm{U}-\mathrm{Pb}$ dating on zircon monocrysts from crosscutting mafic dikes (Dias et al. 1996, Mougeot et al. 1996, Santos 2002).

The Paleoproterozoic is essentially represented by non-deformed metaluminous to peraluminous A-type granites that crosscut the basement and the metavolcano-sedimentary sequences (Dall'Agnol et al. 2005, Vasquez et al. 2008), with ages varying from $1,883 \pm 2$ to $1,874 \pm 2 \mathrm{Ma}$ (Machado et al. 1991, Rämö et al. 2002, Dall'Agnol et al. 2005).

The tectonic setting of the supracrustal units has been attributed to a ca. $2.76 \mathrm{Ga}$ intracontinental rift (Wirth et al. 1986, Gibbs et al. 1986, Docegeo 1988, Macambira 2003) or volcanic arc (Meirelles \& Dardenne 1991, Teixeira 1994, Lindenmeyer et al. 2005, Lobato et al. 2005) built over the > $2.83 \mathrm{Ga}$ Mesoarchean basement. Between 2.76 and $2.70 \mathrm{Ga}$, the $\mathrm{CD}$ is marked by the deposition of the volcano-sedimentary sequences of the Itacaiúnas Supergroup (Docegeo 1988) and mafic-ultramafic and granitic plutonism. The most remarkable CD structures are considered coeval with the $2.76-2.71 \mathrm{Ga}$ type-A granite intrusions (Barros et al. 2001, 2009), a hypothesis also defended by Feio et al. (2013) and Dall'Agnol et al. (2013). These structures have resulted from a NE-SE crustal shortening, which is associated with strike-slip and oblique shear zones in the Itacaiúnas Group rocks and evidenced by an E-W subvertical foliation in basement units. Tectonic reactivation took place at least three times from the Archean to the Paleoproterozoic (Costa et al. 1995, Araújo et al. 1988, Pinheiro \& Holdsworth 2000).

\section{MATERIALS AND METHODS}

During field work in the Cristalino deposit area, nine drillholes (FD-58, FD-96, FD-107, FD-155, FD-209, FD-224, FD-266, FD-325 and DH-00003) were described and several core samples collected for analysis in laboratories housed at the Geosciences Institute of the Universidade Federal do Pará (IG-UFPA). Approximately 100 polished thin sections were prepared for petrographical study under transmitted and reflected light, using a Zeiss Axioplan 40 microscope. Selected thin sections were coated with carbon and then analyzed by 
scanning electron microscopy coupled with energy dispersive $\mathrm{X}$-ray spectrometry (EDS). The equipment was a MEV Zeiss LEO-1430 with EDS IXRF model Sirius-SD that operated under the following analytical conditions: electron beam = $90 \mu \mathrm{A}$; constant acceleration voltage $=20 \mathrm{kV}$; working distance $=15 \mathrm{~mm}$; and counting time to analyze the elements = 30 s. Samples were carbon coated by the metallizer Quorum model Q150T-ES.

\section{RESULTS}

\section{Main lithotypes and structures in the Cristalino copper-gold deposit area}

The main lithotypes identified in the Cristalino deposit area may be grouped into:

1. basement rocks;

2. volcano-sedimentary sequence;

3. mafic/felsic intrusions (Figs. 2 and 3 ).

Mesoarchean basement rocks do not outcrop at the Cristalino deposit area and are recognized only along drill cores. These rocks are mainly represented by the Cruzadão Granite (Fig. 4A), aged 2,857 $\pm 8 \mathrm{Ma}$ (U-Pb in zircon, LA-MCICPMS, Feio et al. 2013). This granite is mainly composed of plagioclase, quartz and rare K-feldspar (Fig. 4B). It is granular to moderately foliated (Fig. 4A) with local cataclastic and recrystallized domains (Fig. 4C). Scapolite, sericite, chlorite, epidote, titanite and hematite are the main alteration minerals. Scapolite (Fig. 4B) selectively replaces plagioclase while sericite tends to overprint both primary and secondary minerals. Chlorite, epidote, titanite and hematite are derived from the biotite alteration.

The volcano-sedimentary sequence in the area consists predominantly of mafic volcanic rocks, generally interlayered with BIF (Figs. 4D and 4E) and felsic units of rhyolitic composition (Fig. 4F). Mafic and felsic volcanic units are stratigraphically correlated with the Parauapebas Formation (2,760 \pm $11-2,757 \pm 7 \mathrm{Ma}$, Trendall et al. 1998), whereas BIF is part of the Carajás Formation. Both the Parauapebas and Carajás formations belong to the Grão Pará Group.

At the deposit scale, mafic volcanics are dark gray to dark green and show different degrees of shearing and hydrothermal alteration that obliterate up to $70 \%$ of their original magmatic mineral assemblages. Actinolite, albite, chlorite, quartz and magnetite are the main hydrothermal products, which have replaced most primary minerals in these rocks (Figs. 4F and 4G). The texture varies from fine- and medium-grained to porphyritic with plagioclase phenocrysts immersed in a microcrystalline matrix. Albite and quartz commonly fill rounded cavities interpreted as vesicles (Fig. 4G). Apatite, allanite, and monazite are subordinate alteration minerals.

The more felsic varieties (Fig. $4 \mathrm{H}$ ) are not abundant in the deposit. They form irregular bodies with thickness up to a few tens of meters. These rocks are greenish gray to reddish green and display a fine-grained isotropic to slightly foliated matrix, commonly porphyritic. Less altered varieties are composed of K-feldspar (30-40\%), plagioclase (10-20\%) and quartz (30-40\%) and have been classified as rhyolite (Fig. 4I). Quartz commonly occurs as bluish phenocrysts immersed in the rock matrix.

At regional scale, BIF form 150 up to $350 \mathrm{~m}$-thick sequences that sustain hills and extend over 3,500 $\mathrm{m}$ along the E-W strike (Fig. 2, Vale 2003). These units are characterized by folded and faulted quartz-rich bands finely interbedded with magnetite-rich bands (Fig. 4D). Calcite and chlorite form several generations of veins that randomly crosscut the BIF. Chalcopyrite (Fig. 4E) and pyrite also occur as alteration products but are spatially related to the interface between $\mathrm{BIF}$ and mafic volcanic rocks.

The volcano-sedimentary sequence is crosscut by the Serra do Rabo Granite and NW-SE-striking gabbro/diabase dikes. The Serra do Rabo Granite was dated at 2,743 $\pm 1.6 \mathrm{Ma}$ (U-Pb in zircon LA-ICPMS, Sardinha et al. 2006) and is confined to the NE sector in the deposit area. This granitic rock shows an hypidiomorphic granular texture with medium to coarse, weakly oriented crystals (Fig. 4J). Graphic texture is locally present. It is mainly composed of plagioclase (40-30\%), quartz (30-40\%) and microcline (10-30\%) and classified as syeno- to monzogranite. No primary mafic mineral is observed. Most plagioclase $\left(\mathrm{An}_{20-28}\right)$ crystals are subhedral and medium- to coarse-grained, and show bookshelf micro-fractures, irregular to recrystallized borders and intra-granular deformation. In general, quartz developed medium- to fine-grained crystals that commonly exhibit undulose extinction, sutured contacts, and recrystallized borders. Microcline develops fine- to medium-grained crystals, some showing flame perthite (Fig. 4K).

The gabbro/diabase dikes crosscut the volcanic rocks and BIF of the Grão Pará Group, show isotropic, subophiotic to granular textures and are mainly composed of fine- to medium-sized pyroxene, calcic plagioclase, and olivine crystals. Minor amounts of epidote and chlorite occur as secondary minerals in the matrix, as well as in veinlets. These dikes have been included in the Neoproterozoic Rio da Onça Gabbro unit (Tavares 2015), but similar rocks have been dated at ca. 2.74 Ga in the Sossego mine (Moreto et al. 2015b).

The main regional structural feature in the southeastern sector of the CD is the Carajás transcurrent system (Vale 2003). At its eastern end, it splays off to the $S$ to form NW-SE-striking faults in a horsetail pattern, in the region known as Serra do Rabo, where the Cristalino deposit is located (Fig. 1B). All these ductile-brittle structures have collectively been associated with a regional sinistral transpression event (ca. $2.7 \mathrm{Ga}$ ) described by Pinheiro \& Holdsworth (2000), responsible for regional shear zones that affected basement rocks and the Itacaiúnas Supergroup units. This system generated a strong mineral orientation (Fig. 5A) and local protomylonitic fabric in the mafic and felsic volcanic rocks and in BIF. Additionally, it reactivated previous structures of the Cruzadão granite. In the deposit area, it accounts also for the mineral lineation (Figs. 5A) and the centimeter-meter oblique shear zones (Fig. 5B) observed in drill core samples of the Parauapebas Formation. 


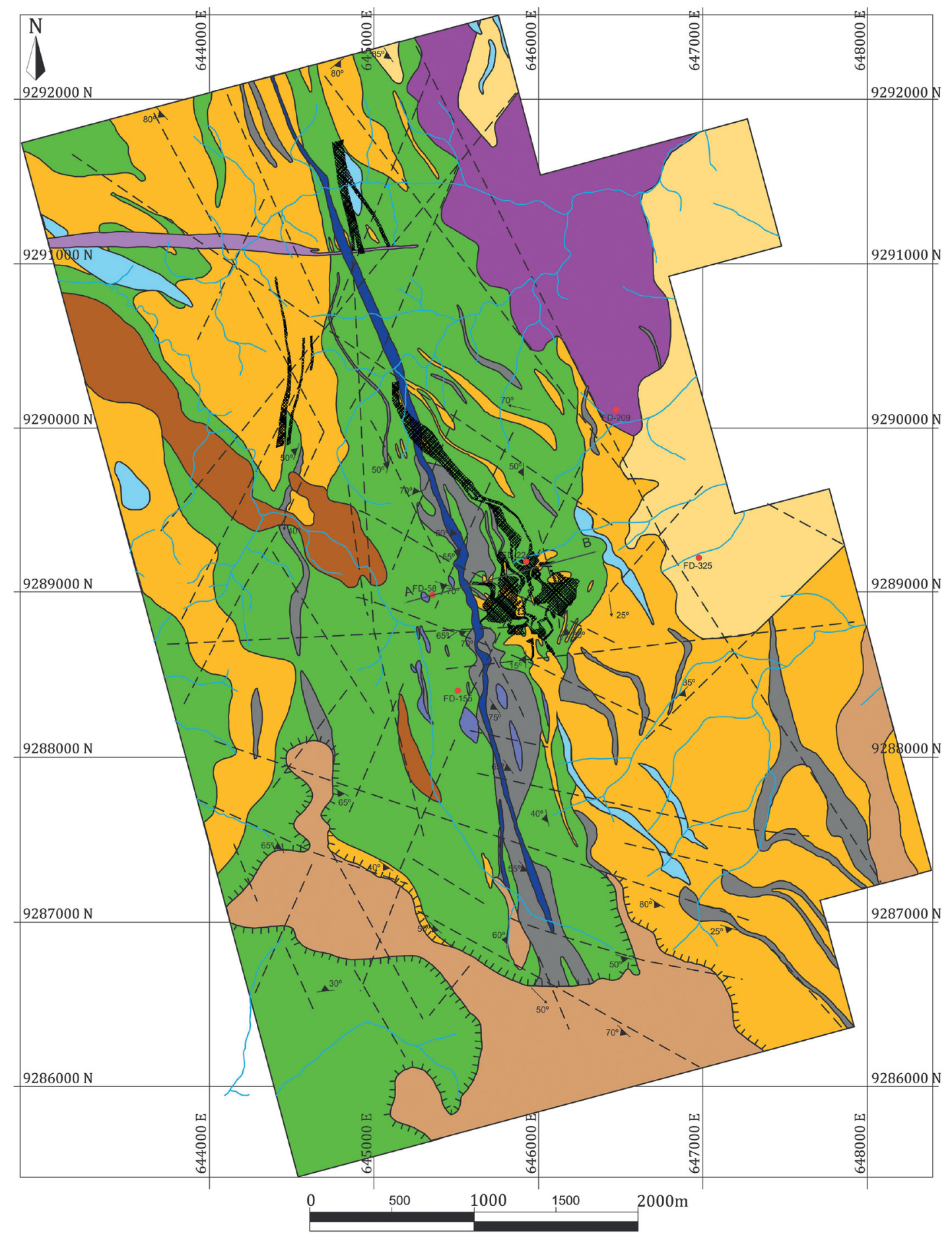

CONVENTIONS

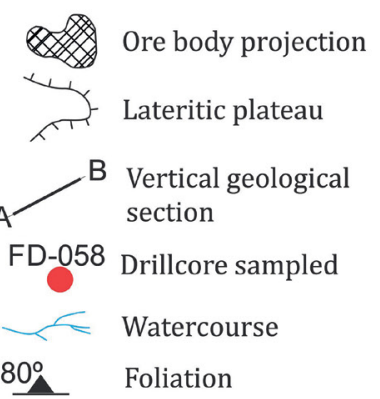

$65^{\circ}$ Foliation and lineation

$\longrightarrow 55^{\circ}$ Fold axis

$\sim$ Geological contact

_- - Principal lineaments

\section{PHANEROZOIC COVER}

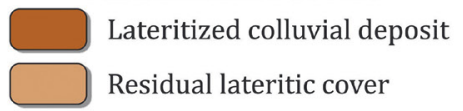
NEOPROTEROZOIC INTRUSIVE UNITS

Rio da Onça Gabbro

\section{NEOARCHEAN - PALEOPROTEROZOIC} COVER UNITS

Águas Claras Formation

\section{NEOARCHEAN UNITS}

Rhyolite

Diabase dikes

Serra do Rabo granite Diorite

Itacaiúnas Supergroup (Grão Pará Group)

CARAJÁS FORMATION

Banded Iron Formation PARAUAPEBAS FORMATION Felsic volcanic rock Mafic volcanic rock

Figure 2. Geological map of the Cristalino deposit area, modified from Soares et al. (2001) and Vale (2003). 
Shearing affected both primary and early alteration minerals, yielding wavy primary quartz that coexists with elongated and rotated tourmaline (Fig. 5A) and allanite crystals (Fig. 5C). Late stages of alteration, however, tend to occur preferably in brittle deformed portions, where $\mathrm{cm}$-thick veins are filled with tourmaline (Fig. 5D), K-feldspar (Fig. 5E) and/ or chlorite-calcite-epidote (Fig. 5F).

Among the nine drill holes studied, the $600 \mathrm{~m}$-deep FD-107 (Fig. 6) is the one that best records the hydrothermal processes that acted in the deposit area. It was drilled near a highly mineralized zone and intercepts comparable thicknesses of mafic and felsic volcanic rocks of the Parauapebas Formation. These rocks show in general well-defined contacts and $\mathrm{cm}$ - to $\mathrm{m}$-thick shear zones as well as several mineralized intervals represented by disseminations, veins and breccias, the latter more commonly developed in the actinolite-magnetite-rich mafic type.

\section{Hydrothermal alteration}

Mafic and felsic volcanic rocks, correlated to the Parauapebas Formation, are the main hosts to the copper-gold mineralization at the Cristalino deposit. These rocks have been subjected to strong hydrothermal alteration that includes an early sodic alteration characterized by widespread formation of albite and local occurrence of scapolite that was subsequently overprinted by a calcic-ferric alteration dominated by actinolite, allanite and magnetite. The ensuing potassic alteration is structurally controlled and observed especially in ductile-brittle sheared domains. It is represented by K-feldspar, biotite, and minor magnetite and hematite. Propylitic alteration, characterized mainly by chlorite, epidote and calcite, took place next under more brittle conditions, overprinting the previous assemblages. The infill stage was the last event of the Cristalino hydrothermal history and is recorded by K-feldspar- and calcite-rich veins that intercept each other, but ambiguously.

\section{Sodic alteration}

This alteration type occurs mainly in distal portions of the deposit and is marked by the development of chessboard albite (Fig. 7A). It confers the rock a pale-yellow to light-rose tint, best recognized in felsic volcanic varieties. This albitization occurs as a textural retentive alteration, leaving residual crystals of primary K-feldspar associated with decalcified plagioclase (An $<10)$ with turbid aspect, suggesting that this process was accompanied by an incipient sericitization. Quartz and REE minerals, such as allanite (Fig. 7B) and monazite (Fig. 7C), are also seen associated with hydrothermal albite.

Scapolite was only observed away from the mineralized zones in the Cruzadão granite, where it shows deformed crystals (Fig. 4B). It is considered a product of sodic alteration as it is in other copper-gold deposits of the Carajás Province (e.g., Visconde and Borrachudo; Silva et al. 2015, Previato 2016).

\section{Calcic-ferric alteration}

This is best developed in the mafic volcanic rocks, where it severely obliterates the primary mineral assemblages by forming actinolite and magnetite. The common light to dark green color acquired by these rocks results from the lesser or greater abundance of actinolite (Fig. 7D) that preferably replaced ferromagnesian minerals and was later replaced by

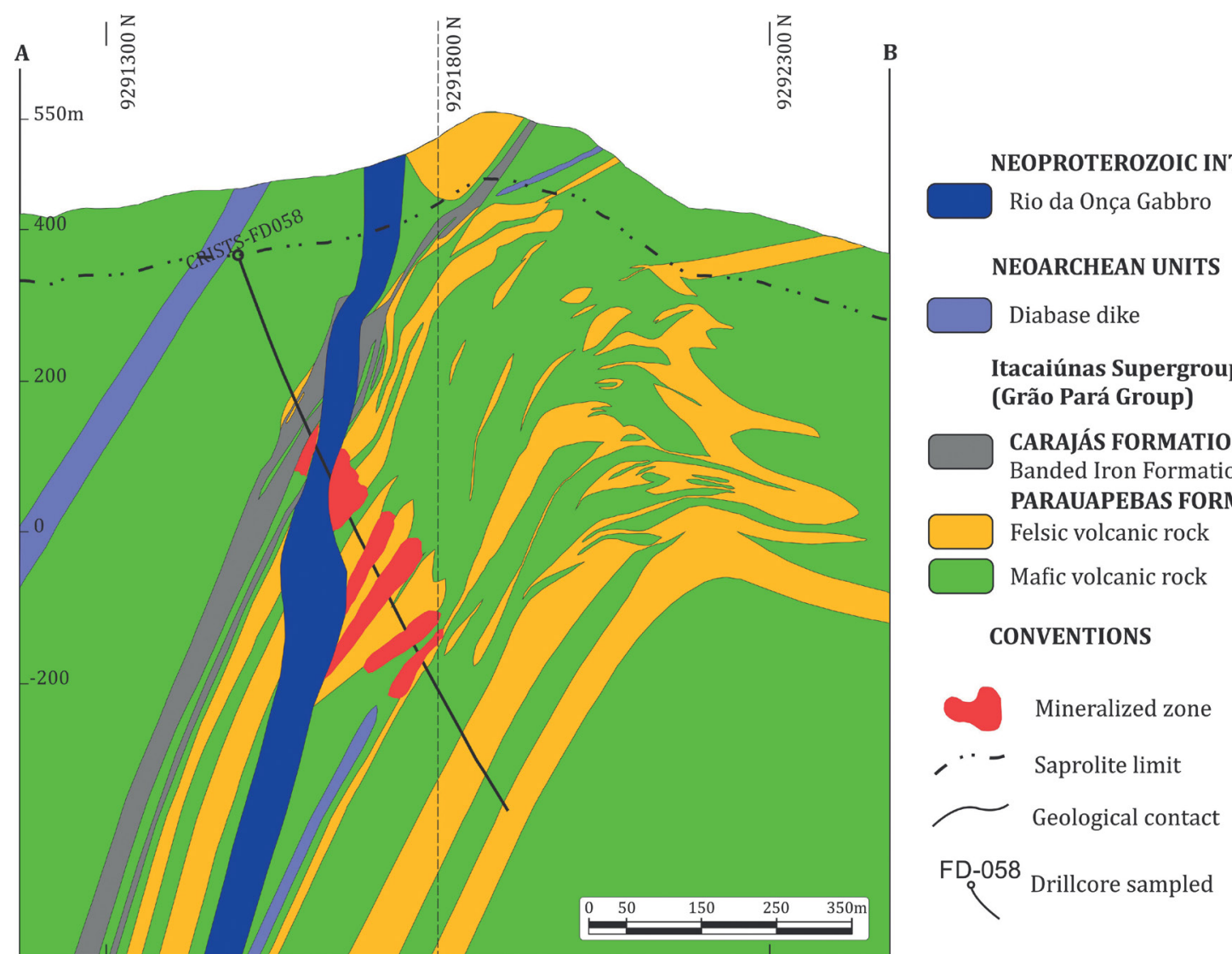

Figure 3. $\mathrm{N}^{\circ} 5^{\circ} \mathrm{E}$ geological section across the mineralized zone of the Cristalino deposit (A-B line in figure 2), modified from Vale (2003). 
chlorite. Actinolite forms fine- to coarse-grained aggregates, being locally represented by acicular crystals. In turn, magnetite appears disseminated as $\mathrm{cm}$-thick clusters, closely associated with the actinolite-rich zones (Figs. 6D and 7B).

Allanite is subordinate but of common occurrence in the calcic-ferric alteration assemblages, in contact with magnetite or intergrown with actinolite (Fig. 6D). It forms finegrained aggregates or coarse-grained zoned crystals that present metamitic halos and borders that normally grade to epidote. Additionally, rare uraninite occurs associated with allanite.

Apatite and epidote occur as subordinate constituents of the calcic-ferric assemblage and seem to be later than the actinolite-magnetite-allanite association. They are normally observed replacing early hydrothermal minerals, including monazite of the sodic alteration Fig. 7C).

Locally, hastingsite/edenite, associated with quartz, occurs as fine-grained crystals that replace actinolite aggregates,
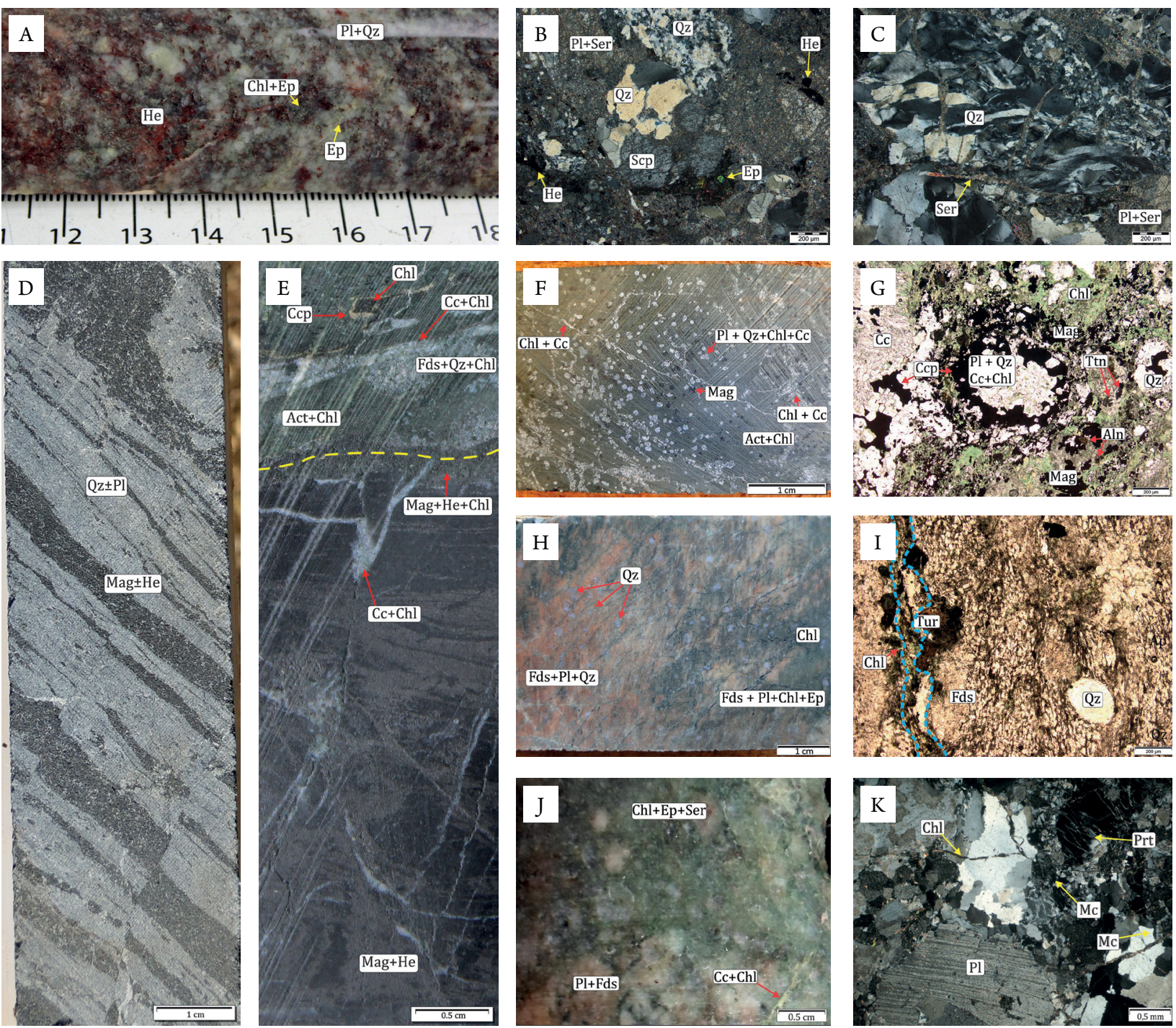

Act: actinolite; BIF: banded iron formation; Cc: calcite; Ccp: chalcopyrite, Chl: chlorite; Ep: epidote; Fds: feldspar; He: hematite; Mag: magnetite; Mc: microcline; Pl: plagioclase; Pr: perthite; Qz: quartz; Ser: sericite; Scp: Scapolite; Ttn: titanite; XPL: crossed polars; PPL: parallel polors.

Figure 4. Main lithotypes of the Cristalino deposit area: (A) Cruzadão granite showing typical granular texture. The red spots correspond mostly to hematite-stained plagioclase and quartz, whilst the light-grey and dark-grey spots are, respectively, plagioclase and quartz, and chlorite-hematite \pm epidote. Scale is in $\mathrm{cm}$. (B) Photomicrograph (transmitted light - XPL) of the Cruzadão metagranite strongly altered to sericite, although a few plagioclase crystals are still recognizable. Quartz occurs as anhedral crystals some forming microcrystalline aggregates. Epidote and hematite occur as fine interstitial crystals. (C) Same as B, showing the strained portions of Cruzadão granite, with deformed and fragmented quartz crystals. (D) Banded iron formation showing disrupted and fractured quartz-rich bands interleaved with magnetite-hematite-rich bands. (E) Sharp contact (dashed line) between strongly altered volcanic rock (upper part) and BIF (lower part); (F) Hydrothermally-altered mafic volcanic rock composed of quartz, actinolite, plagioclase, chlorite, and magnetite. Note the presence of vesicles (white spots), filled with plagioclase, quartz, chlorite, and calcite. (G) Photomicrograph (transmitted light — PPL) of altered mafic volcanic rock depicted in F showing chlorite as the main alteration mineral. Chalcopyrite replaces selectively vesicular minerals. Magnetite and allanite are alteration minerals, and both are corroded by chlorite; $(\mathrm{H})$ Potassic-altered rhyodacite with bluishquartz phenocrysts and fractures filled by chlorite. (I) Photomicrograph (transmitted light — PPL) of altered rhyodacitic rock depicted in $\mathrm{H}$, showing relic feldspar, quartz, and tourmaline, with chlorite and calcite filled veinlet (between dashed lines); ( J) Coarse-grained Serra do Rabo granite with green (chlorite-sericite-epidote) and the pink patches that represent, respectively, strongly, and less altered portions of the rock. (K) Photomicrograph (transmitted light - XPL) of the Serra do Rabo granite showing oligoclase, microcline/perthite and quartz as essential minerals. Sericite and chlorite are the most common alteration minerals. The scale in A photograph is in centimeter. 
particularly in portions of mafic volcanic rocks, implying a second generation of hydrothermal amphibole.

\section{Potassic alteration}

The sodic and calcic-ferric alteration assemblages are partially overprinted by potassic alteration, which is characterized by K-feldspar and, to a lesser extent, biotite. The potassic alteration and infill are better developed along lithological contacts, foliation planes, fault gashes and fractures (potassic alteration I). A second and less important potassic alteration marks the final stage of the hydrothermal alteration at the Cristalino deposit. It is fissure-controlled and has K-feldspar as the only potassic mineral (potassic alteration II).

Biotite (Fig. 7E) grew over sodic and calcic-ferric alteration minerals without showing distinct halos of biotitization. Locally, it coexists with magnetite and is also recognized as fine lamellae on mylonitic foliation planes, where it is partially altered by chlorite.

Hydrothermal K-feldspar forms centimeter-sized aggregates (Fig. 7E) that partially replace actinolite, albite, and apatite. Commonly, hydrothermal K-feldspar presents reddish coloration in hand specimens and turbid crystals in thin-sections, probably due to the very minute hematite inclusions.

Veins related to the potassic alteration II transect lithological contacts and foliation planes, as well as zones previously affected by sodic and calcic-ferric alterations. A few show mmto $\mathrm{cm}$-thick halos and are composed of K-feldspar, quartz and minor albite, hematite, titanite and sulfides.

\section{Tourmaline formation}

The temporal relationships of the different generations of tourmaline are not always straightforward, but at least two tourmaline generations are defined with a good degree of confidence.

The early event is especially recorded in sodic and calcic-ferric altered samples. Tourmaline occurs as green to dark brown, medium- to coarse-grained crystals, with several quartz inclusions, associated with chessboard albite, allanite and monazite. It is a textural retentive alteration, in which tourmaline crystals were probably formed at the expense of primary plagioclase of the wall rocks. In deformed domains, tourmaline crystals show undulose extinction and microfractures and are oriented along with bluish quartz and allanite crystals, defining a mineral lineation (Figs. 5A and 7B).

The other generation, relatively more expressive, is spatially associated with potassic altered felsic volcanic rocks. Along with quartz and minor albite, tourmaline forms centimeter clusters of fine- to medium-grained zoned crystals that replace earlier minerals (Fig. 5B). Locally tourmaline may exceed $60 \%$ of the wall rock minerals.

Unpublished data on the chemistry of these tourmalines (Craveiro et al., 2018) reveal that those of schorlitic composition are more common in association with sodic and calcic-ferric alteration, whereas those of dravitic composition grew mainly during the main tourmaline-forming event.

\section{Propylitic alteration}

Developed at the vicinity and along shear zones, lithological contacts and fracture planes, the propylitic alteration clearly overprints the potassic zones and most of the previous mineral assemblages. This alteration is represented by the chlorite-epidote-calcite assemblage (Fig. $7 \mathrm{H}$ ) and by an array of veinlets composed mostly of calcite with variable amounts of chlorite, epidote and sulfides, and minor contents of albite, hematite,
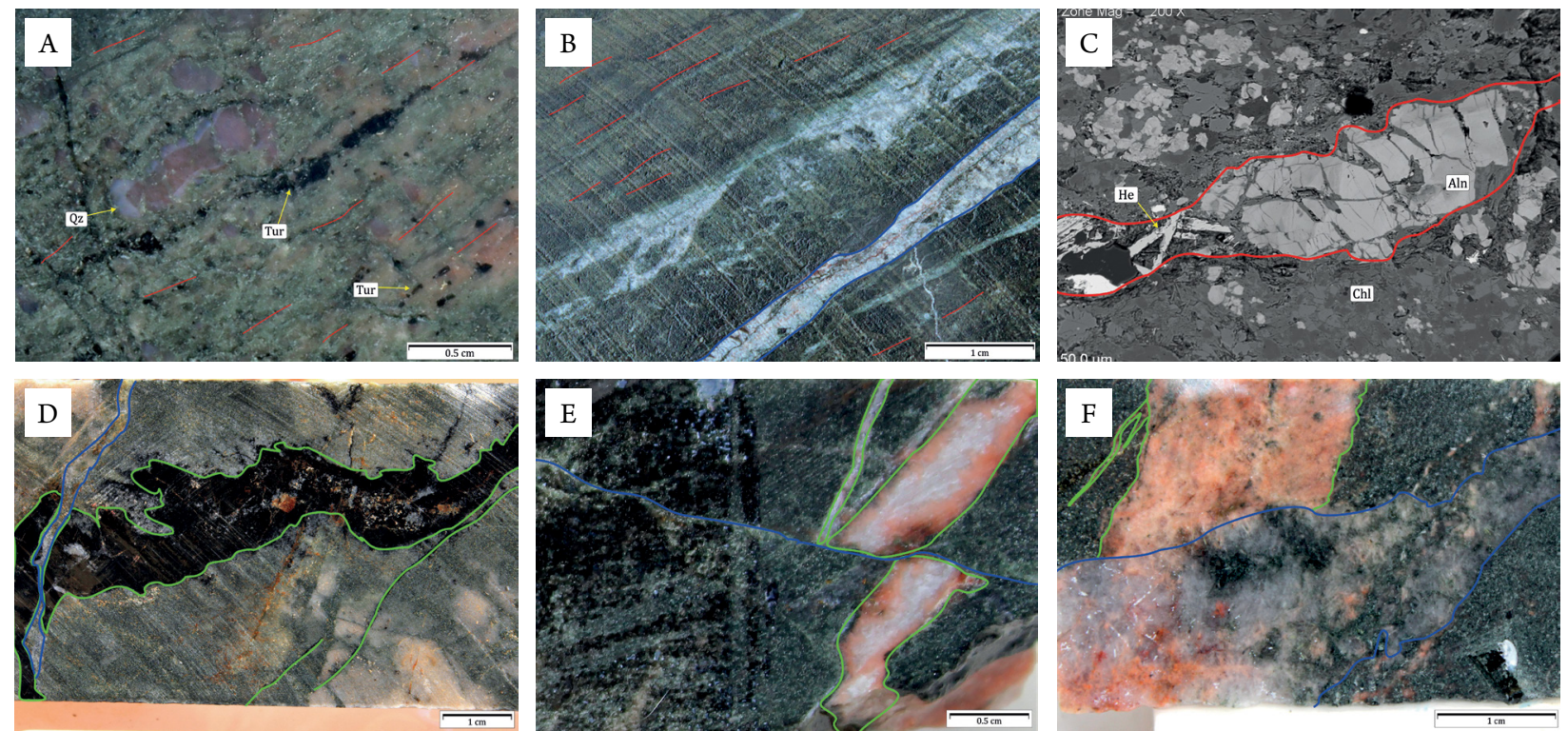

Aln: allanite; Chl: chlorite; He: hematite; Qz: quartz; Tur: tourmaline.

Figure 5. Main types of microstructures observed in the host rocks of Cristalino deposit. Photographs of borehole samples, except in C. (A) Mineral lineation (highlighted as red lines) defined by deformed blue quartz and oriented strings of tourmaline in a chloritized felsic volcanic rock. (B) Centimeter shear zone developed in chloritized mafic volcanic rock (shear zone sense highlighted as red lines). In the lower right corner, dilatant fracture (between blue lines) filled mostly by calcite. (C) Back-scattered electron image showing an oriented, deformed and cracked allanite crystal, defining a mineral lineation (lineation sense highlighted as red lines). (D) Tourmaline-rich vein (green lines) with diffuse borders crosscut by a calcite veinlet (blue lines). (E) Faulted K-feldspar-quartz-calcite vein (between green lines) crosscutting the chloritized felsic volcanic rock. The fault plain is filled with chlorite and calcite (blue line). (F) K-feldspar vein (between green lines) crosscut by quartz-calcite-K-feldspar-chlorite vein (between blue lines) in volcanic rock. 


\section{FD-107 profile representation}
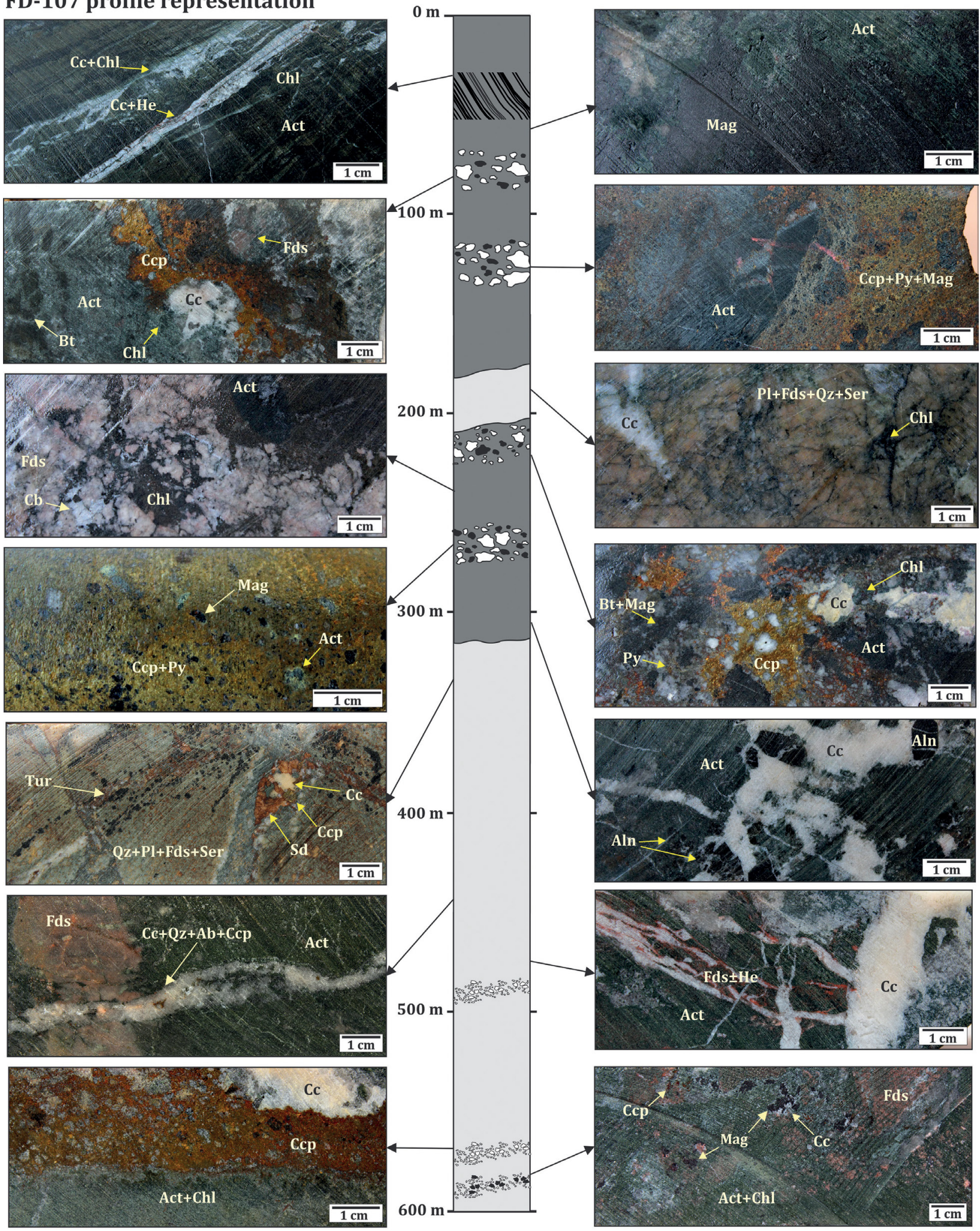

LEGEND

Parauapebas Formation

Mafic Volcanic Rock Felsic Volcanic Rock

$$
\begin{aligned}
& \text { Shear zone } \\
& \text { (Ccp+Py+Mag+Au) }
\end{aligned}
$$$$
\text { Conventions }
$$

Act: actinolite; Aln: allanite; Bt: biotite; Cb: carbonate; Cc: calcite; Ccp: chalcopyrite; Chl: chlorite; Fds: potassic feldspar; He: hematite; Mag: magnetite; Py: pyrite; Qz: quartz; Ser: sericite; Sd: siderite; Tur: tourmaline.

Figure 6. Logging of the 600-m drill-hole FD-107 showing the distribution of mafic and felsic volcanic rocks of the Parauapebas Formation, contact relationships, mineralized zones and main alteration minerals. 
allanite and titanite. It seems that the propylitic alteration grades into carbonatization. Calcite is by far the most abundant veinlet constituent, so that the latter mode of occurrence should be more properly attributed to carbonatization, thus recording one of the latest hydrothermal processes in the Cristalino system.

The growth of the chlorite-epidote-calcite assemblage was a texture destructive process and was best developed in mafic volcanic rocks as the result of the partial to total replacement of groundmass minerals. Locally, calcite-rich veinlets generated breccias bodies with multi-mineral matrix and supported angular lithic clasts. Musketovite (magnetite after hematite) is confined to the veinlets and breccia matrix associated with chlorite, epidote, calcite and, chalcopyrite. Carbonates (mainly calcite and minor dolomite and siderite, see Fig. 8) were the last minerals to be formed during both the pervasive propylitic alteration and veining stage.

Locally, portions that formerly underwent chloritization are partially taken over by a new generation of
K-feldspar. Likewise, breccias hosted by felsic volcanic rocks exhibit chloritized lithic clasts that are rimmed by K-feldspar-rich aureoles.

\section{Cu-Au mineralization styles and ore mineral associations}

The $\mathrm{Cu}-\mathrm{Au}$ mineralization at the Cristalino deposit is dominantly hosted by volcanic rocks of the Grão Pará Group and based on its modes of occurrence may be grouped in the following types:

1. disseminated;

2. breccias (magnetite-chalcopyriteand chalcopyrite-hematite-rich);

3. sulfide-bearing veins.

\section{Disseminated type}

The disseminated mineralization occurs preferably along shear zones, close to contacts between the Parauapebas and
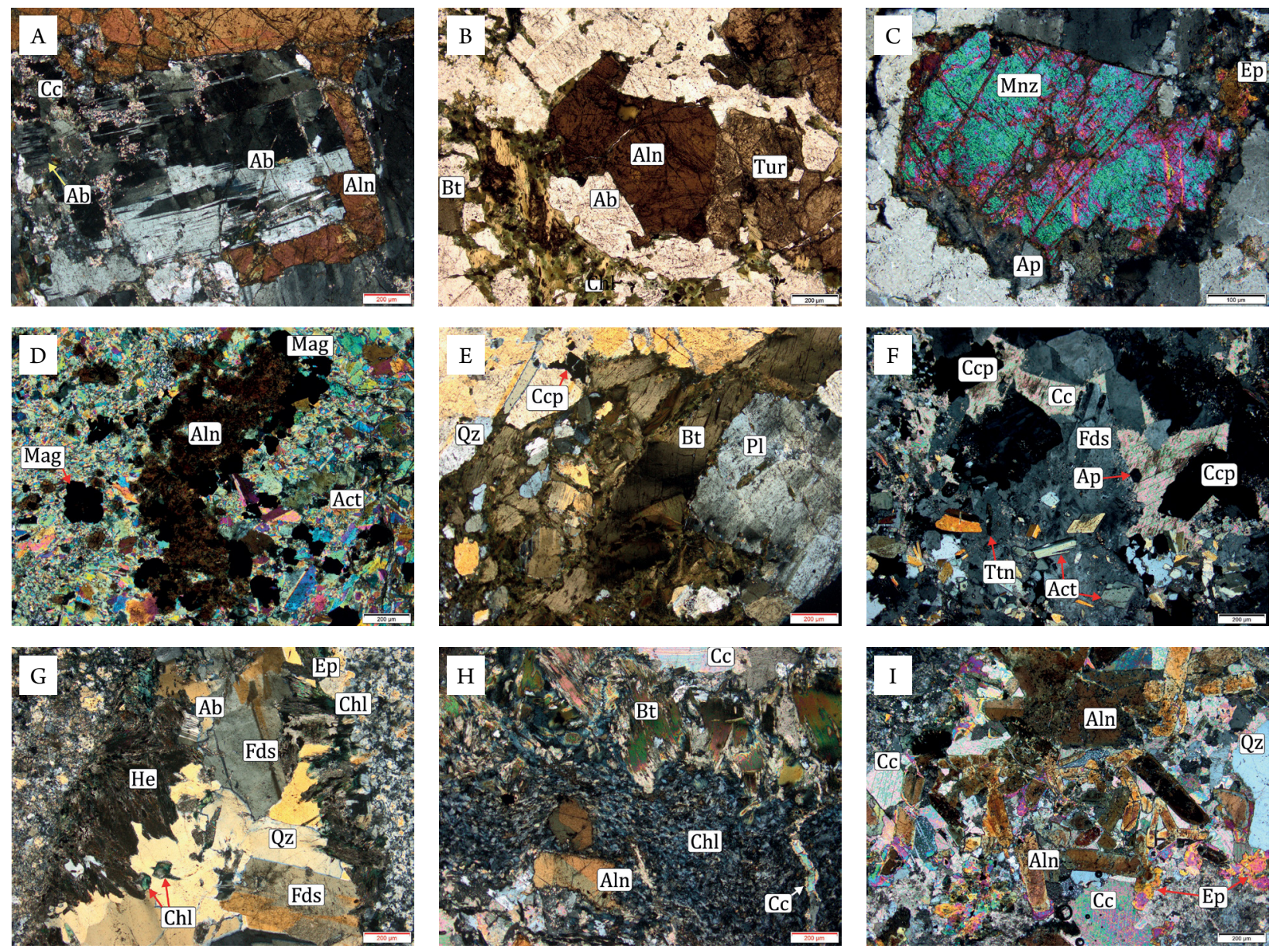

Ab: albite; Act: actinolite; Aln: allanite; Ap: apatite; Bt: biotite; Cc: calcite; Ccp: chalcopyrite; Chl: chlorite; Ep: epidote; Fds: K-feldspar; He: hematite; Mag: magnetite; Qz: quartz; Ser: sericite; Tur: tourmaline; Ttn: titanite; XPL: crossed polars; PPL: parallel polors.

Figure 7. Photomicrographs (transmitted light) of the main types of hydrothermal alteration at the Cristalino deposit. (A) Altered felsic volcanic rock displaying a slightly deformed chessboard albite and coarse-grained allanite, partially taken by late calcite (XPL). (B) Albitized felsic volcanic rock with late medium-grained allanite, tourmaline and chlorite (PPL). (C) A monazite crystal in felsic volcanic rock matrix replaced by apatite and epidote along the borders (XPL). (D) Abundant actinolite \pm magnetite produced during Ca-Fe alteration in mafic volcanic rock. Actinolite occurs as fine- to medium-grained crystals and microcrystalline aggregates coexisting with magnetite and chalcopyrite (PPL). (E) Potassic alteration represented by hydrothermal biotite in a felsic volcanic rock (PPL). (F) Felsic volcanic rock with subhedral actinolite crystals engulfed by secondary K-feldspar and chalcopyrite. Calcite is the last mineral to precipitate (XPL). (G) Sericitized volcanic rock crosscut by a veinlet composed of K-feldspar, quartz, hematite, chlorite and minor epidote and albite (PPL). (H) Chlorite mass replacing allanite and biotite in a mafic volcanic rock (XPL) and crosscut by a calcite veinlet (lower right corner). (I) Portion of a calcite-veinlet (carbonate stage) with high concentration of allanite and epidote that crosscuts an altered felsic volcanic rock (XPL). 

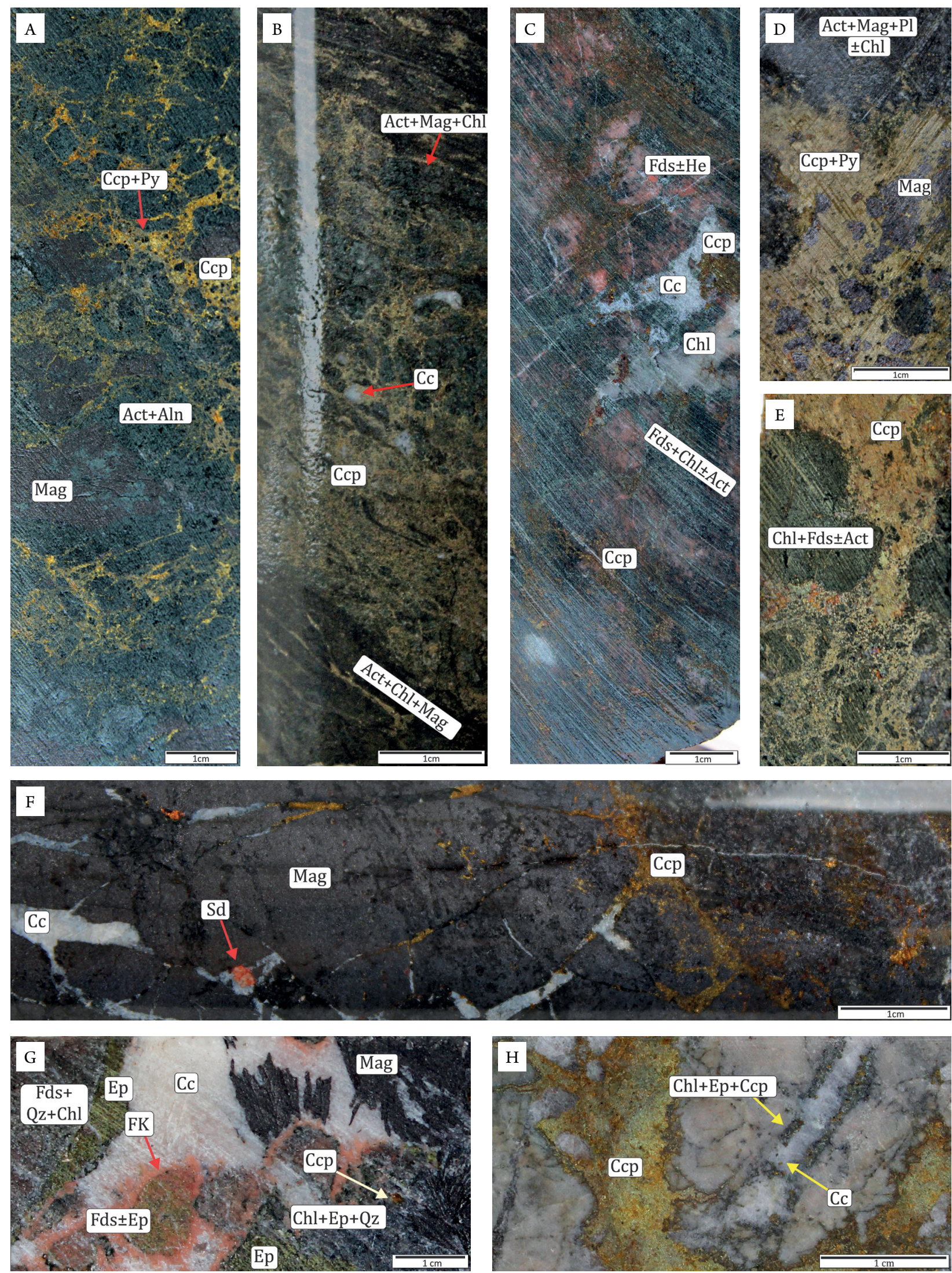

Act: actinolite; Cc: calcite; Ccp: chalcopyrite; Chl: chlorite; Ep: epidote; Fds: K-feldspar (group); He: hematite; Mag: magnetite; Py: pyrite, Qz: quartz, Ser: sericite.

Figure 8. Photographs of mineralized samples of boreholes from the Cristalino deposit. (A) Mafic volcanic-hosted sulfide-rich breccia with clasts containing actinolite, magnetite and allanite and essentially with chalcopyrite and pyrite. (B) Disseminated chalcopyrite-pyrite along shear zones, in actinolite-magnetite-allanite (Ca-Fe alteration) in mafic volcanic rock. (C) Disseminated chalcopyrite in felsic volcanic rock altered by actinolite (Ca-Fe alteration), K-feldspar hematite (potassic alteration) and chlorite-calcite (propylitization/carbonation). (D) Chalcopyrite-magnetite breccia type, in mafic volcanic rock affected by Ca-Fe alteration. (E) Chalcopyrite-rich type breccia, in deeply altered felsic volcanic rock, affected by Ca-Fe and potassic with K-feldspar alteration. (F) Magnetite alteration in mafic volcanic rock, near banded iron formation contact, invaded and fractured by calcite-chalcopyrite rich veins. (G) Felsic volcanic rocks affect by superposition of potassic alteration with K-feldspar and propylitic alteration. This portion in crosscut by calcitemusketovite \pm chalcopyrite vein. Lithic clasts coated by K-feldspar within calcite-rich veins suggest a local superposition of calcite-vein over K-feldspar vein. $(\mathrm{H})$ Felsic volcanic rock transected by multidirectional calcite-chlorite-epidote veins and later chalcopyrite-rich veins. 
Carajás Formations, where it is commonly involved by zones of calcic-ferric and potassic alteration I.

Two types of disseminated ore could be distinguished:

1. chalcopyrite, pyrite, and magnetite (up to 50\%) with minor amounts of millerite and galena, and rare gold inclusions in sulfides. It generally occurs in mafic volcanic rocks affected by $\mathrm{Ca}-\mathrm{Fe}$ alteration, in both isotropic (Figs. 8A and 9A) and deformed portions along shear zones (Fig. 8B). Locally, this type of ore is found in felsic volcanic rocks affected by potassic alteration with biotite (Fig. 9B);

2. chalcopyrite (ca. $80 \%$ ) with minor pyrite and almost magnetite-free (Figs. 9B and 9C), present in the felsic volcanic rocks affected by potassic alteration I and propylitic alteration. Moreover, when present, the scarce magnetite is partially replaced by hematite (martite).
In both cases, the sulfides precipitated during most of the calcic-ferric and potassic alterations, the final stages recording exclusively chalcopyrite. Although generally formed earlier than sulfides, some allanite crystals from the $\mathrm{Ca}-\mathrm{Fe}$ alteration present ambiguous textural relationships with chalcopyrite, suggesting intergrowth between these two minerals. Locally, covellite and digenite, present in both disseminated ore types, have resulted from weathering processes on chalcopyrite (Fig. 9D).

\section{Breccias}

Mineralized breccias are generally located in central portions of disseminated zones or preferably along lithological contacts and dilatant structures as well. Two types of breccia could be distinguished:

1. Chalcopyrite-pyrite-magnetite bodies;

2. chalcopyrite \pm pyrite \pm hematite bodies.
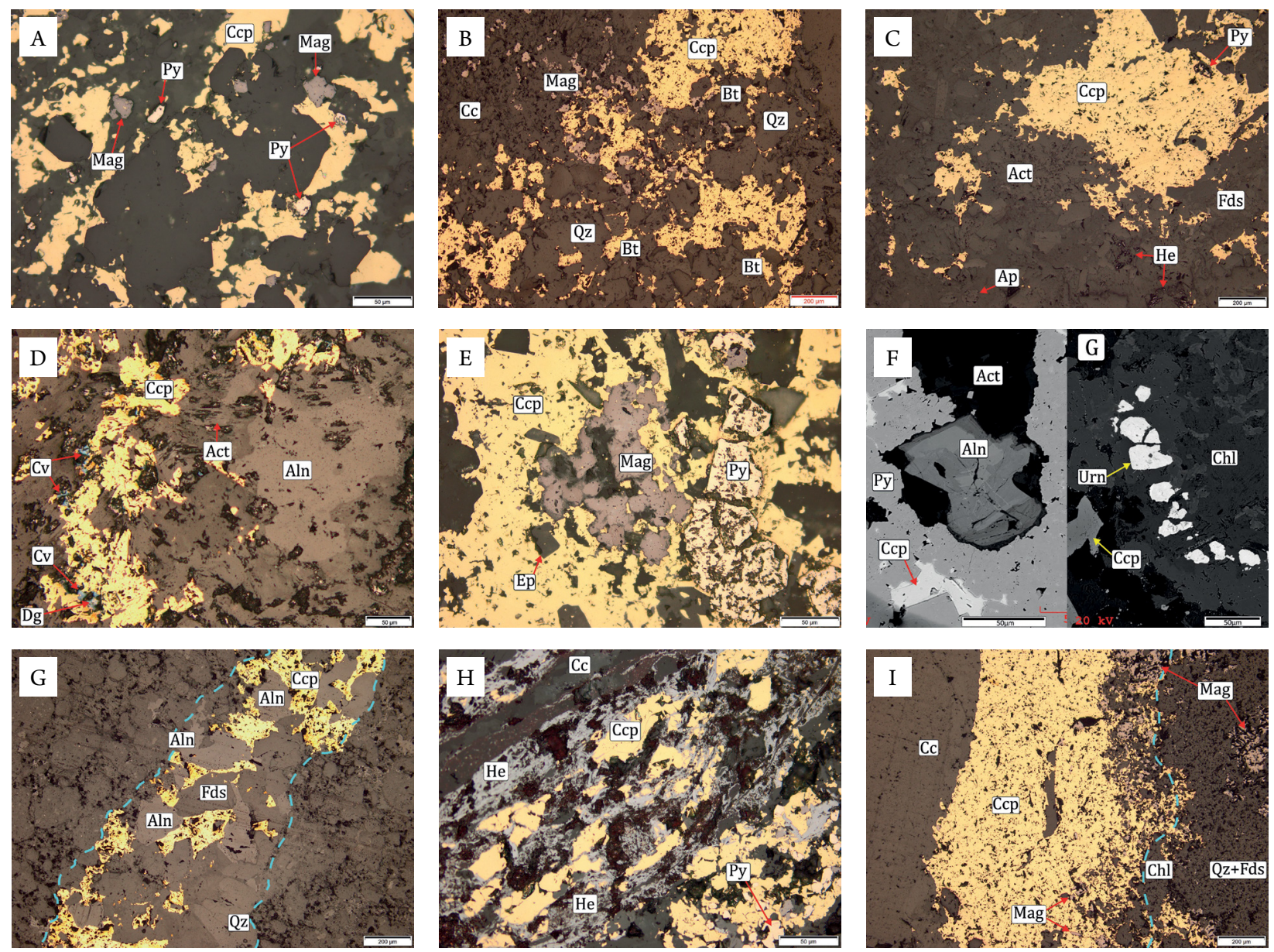

Act: actinolite; Aln: allanite; Ap: apatite; Bt: biotite; Cc: calcite, Ccp: chalcopyrite; Cv: covellite; Dg: digenite; Ep: epidote; Fds: K-feldspar; He: hematite; Mag: magnetite; Py: pyrite; Qz: quartz, Urn: uraninite; PPL: parallel polors.

Figure 9. Photomicrographs of the $\mathrm{Cu}-\mathrm{Au}$ mineralization types of the Cristalino deposit. All images are taken under reflected light and PPL, except for C, F, and I which are back-scattered electron microscope images. (A) Disseminated type with chalcopyrite and pyrite in an altered mafic volcanic rock. Magnetite crystals present minute inclusions of chalcopyrite, suggesting a generation of sulfide prior to the precipitation of the iron oxide. (B) Chalcopyrite and magnetite disseminated in felsic volcanic rocks altered potassic alteration with biotite and propylitic alteration with calcite. (C) disseminated type with chalcopyrite only, in felsic volcanic rock altered by actinolite-apatite (Ca-Fe alteration) and $\mathrm{K}$-feldspar (potassic alteration). (D) Covellite and digenite resulting from the supergene alteration of chalcopyrite in an actinolite-magnetiteallanite altered mafic volcanic rock; (E) Sulfide-rich breccia within the Ca (actinolite) - Fe (magnetite) alteration zone in volcanic rock. Magnetite and pyrite are partially to totally replaced by chalcopyrite. (F) Allanite immersed in a pyrite-rich mass within a mafic volcanic rock. Chalcopyrite is included in pyrite. (G) A string of uraninite crystals in a chloritized mafic volcanic rock. (H) K-feldspar-rich veinlet (late potassic alteration) with comb-like quartz, allanite and chalcopyrite. Dashed lines highlight the vein walls. (I) A vein composed of calcite, chalcopyrite, hematite and minor pyrite, crosscutting a propylitic altered mafic volcanic rock. ( $\mathrm{J}$ ) Calcite-rich vein with chalcopyrite in a felsic altered volcanic rock. The contact of chalcopyrite with the wall rock is diffuse, creating an alteration halo. The dashed line traces the vein wall. 
The cm-thick chalcopyrite-pyrite-magnetite bodies (Figs. 8D and 9E) formed under ductile-brittle conditions (dominance of shear zones over fractures) at the vicinity of zones enriched in magnetite and are generally hosted by mafic volcanic rocks that were priorly affected by calcic-ferric alteration. Chalcopyrite and pyrite occur in different proportions replacing the wall rock that is currently represented by $\mathrm{mm}$-thick, fine to medium-sized clasts containing magnetite (up to $30 \%$ ), actinolite, allanite and other calcic-ferric minerals (Fig. 9B). These mineralized breccias grade into disseminated chalcopyrite-pyrite ore bodies.

The chalcopyrite \pm pyrite \pm hematite bodies (Fig. $8 \mathrm{E}$ ) formed under dominantly brittle conditions (abundance of fractures) and occur particularly in felsic volcanic rocks that were affected by potassic alteration I, followed by propylitization/carbonatization. Chalcopyrite is the principal constituent of the matrix, which shows practically neither pyrite nor magnetite, but instead contains hematite. These breccias vary from clast- to matrix-supported, with altered rock clasts composed of K-feldspar, hematite, allanite, epidote, chlorite, calcite, and quartz. These breccia bodies grade into an array of multidirectional chalcopyrite-rich veinlets.

As the textural relationships suggest, and similarly to the dissemination types, chalcopyrite is the latest sulfide to form in the breccias, partially replacing pyrite (Fig. 9E) and most of the previous alteration minerals. Even when pyrite is the dominant matrix sulfide, chalcopyrite occurs interstitially (Figs. 8F and 9F). Some allanite grains from the Ca-Fe alteration, however, are apparently neoformed and occur in textural equilibrium with the sulfide matrix. Minor millerite, galena and rare uraninite (Fig. 9G) are seen in massive chalcopyrite of type 1 breccias.

\section{Sulfide-bearing veins}

Most sulfide-bearing veins are discordant to lithological contacts and mylonitic foliation developed in high strain shear zones at the Cristalino deposit. These veins can be divided into three main types according to their prevalent mineral composition:

1. K-feldspar-rich veins;

2. calcite-rich veins;

3. chalcopyrite-rich veins.

Relatively to the other types, calcite-rich veins are the most abundant ones and generally crosscut K-feldspar-veins, while chalcopyrite-rich veins are the scarcest and locally crosscut the other two types.

K-feldspar-rich veins fill millimeter-thick fractures and faults and may represent the late stage of the potassic alteration. In addition to K-feldspar and scarce chalcopyrite (Fig. 9H), the veins consist of fine-grained hematite, quartz, allanite, epidote, titanite, albite, and calcite.

Calcite-rich veins belong to the late stages of propylitization/carbonatization and resulted from the filling of millimeter-thick dilatant structures. They generally display sharp walls and crosscut all varieties of volcanic rock (Fig. 8G). Other mineral constituents include variable amounts of chalcopyrite and pyrite both in equilibrium with hematite and musketovite (Fig. 8G). Locally, millimeter-sized allanite grains can be found in these veins (Fig. 9I).

Millimeter-thick chalcopyrite-rich veins (Figs. $8 \mathrm{H}$ and 9J) show a non-uniform spatial distribution and are essentially composed of chalcopyrite. These veins/veinlets are probably a subcategory of the calcite-rich veins, in which sulfides replace, and seldom crosscut, calcite and other vein minerals.

\section{DISCUSSION}

The volcanic rocks that host the Cristalino deposit show no evidence of regional metamorphism, although Ribeiro et al. (2009) argue that they are metamorphosed at the greenschist to amphibolite facies conditions. In fact, the volcanic rocks are affected by centimeter- to meter-thick brittle-ductile shear zones, causing them to acquire protomylonitic texture. Most likely, the complex history of the region involving deformation, hydrothermal alteration and reactivation along the Carajás fault has led to the false interpretation that these rocks have been submitted to a regional metamorphism.

Zones affected by sodic and calcic-ferric alterations present deformed and mosaic-like crystals of allanite (Fig. 5C) and early tourmaline, whilst zones of potassic alteration show not only oriented biotite lamellae within local shear zones but also K-feldspar-bearing veins. In later alteration stages, the assemblage chlorite-epidote-calcite tends to be associated with dilatant structures. These features may suggest that the deformational environment changed from ductile-brittle to dominantly brittle throughout the evolution of the hydrothermal system.

Regional circulation of hot and hypersaline fluids through the CD units most likely brought about the sodic alteration and the input of metals leached from the rocks. As a result, these fluids became metalliferous and were ultimately responsible for the formation of Archean IOCG deposits. The origin of this hypersaline fluid is debatable. Some authors consider it of magmatic origin and related to Neoarchean granitoids (Tallarico et al. 2005, Grainger et al. 2008), whereas others defend a hybrid hydrothermal system in which marine-evaporitic beds played an important role as source of the fluid halogens and alkalis (Xavier et al. 2008, 2012, Moreto et al. 2015a, 2015b).

The ensuing calcic-ferric alteration overprinted the sodic mineral assemblage in the mineralized zones of the Cristalino area. Especially recognized in mafic volcanic rocks, allanite continued to precipitate signalizing a possible transition between sodic and calcic-ferric alterations. The ductile-brittle regime persisted during this transition, but at different physico-chemical conditions, which allowed precipitating calcic minerals and magnetite. After most magnetite has been formed, chalcopyrite and pyrite started to precipitate as disseminations. Towards the end of the Ca-Fe alteration, chalcopyrite-pyrite-magnetite breccia-like bodies were also developed with diffuse contacts, suggesting the replacement of the wall rocks by sulfides. 
This ore association marks the first mineralization stage (Fig. 10A) that has been recognized in the Cristalino deposit. The source of iron is uncertain, although host rocks may be the most important reservoir. Despite the pervasive character of the calcic-ferric alteration, magnetite concentrates in mafic volcanic rocks, possibly due to its ferromagnesian primary minerals, which were partly destabilized to form hydrothermal iron oxides. On the other hand, little magnetite was observed in the Ca-Fe altered felsic rocks, showing actinolite marginally associated with iron oxide.

As the calcic-ferric minerals stabilized, the solutions had reached a level of temperature that may have allowed a local formation of the hastingsite-quartz assemblage. It may represent a discrete calcic-sodic alteration that is evidently later than the calcic-ferric alteration, since it acted upon rocks previously altered to actinolite-magnetite-allanite.

Later on, a new mineralization stage came into scene, generating the chalcopyrite \pm pyrite \pm hematite ore association with practically no magnetite, especially in breccias and veins. This virtually magnetite-free ore represents a second mineralization stage (Fig. 10B) in the Cristalino area. Its formation coincides with the potassic alteration that affected the host rocks, notably the felsic volcanic rocks. The temporal relationship between biotite and K-feldspar (Fig. 6E), the diagnostic minerals of the potassic alteration, is dubious. However, if the hydrothermal system evolved with increasing $f_{\mathrm{O} 2}$, the precipitation of the biotite-magnetite pair should have preceded the K-feldspar-hematite pair.
Based on the identified ore associations, it is plausible to assume that the fluid was initially less oxidizing and with lower $\mathrm{Cu} / \mathrm{Fe}$ ratio and became more oxidizing (precipitation of hematite) and with higher $\mathrm{Cu} / \mathrm{Fe}$, largely inhibiting pyrite formation. Moreover, given that the brittle conditions are more prone to exist at shallower depths, the infiltration of surficial waters might have also contributed to the $f_{\mathrm{O} 2}$ increase during the second mineralizing stage, allowing the formation of hematite.

As alteration advanced, the fluid became K-depleted due to the formation of K-feldspar and biotite, whereas calcium and carbonate species, among other components, had their concentrations relatively increased. These new chemical conditions combined with the progressive fall in temperature brought about the deposition of chlorite, epidote, and calcite. This mineral association commonly includes hematite or martite, representing a low temperature alteration assemblage marked by an overall loss of silica (abundance of chlorite), under oxidizing and acidic conditions. This propylitic alteration evolved to carbonatization. Apparently, the solutions were still reactive to remove $\mathrm{Ca}$ from the host rocks and to precipitate it, especially as calcite, with minor chalcopyrite, on multi-directional fracture planes. The second mineralization stage seems to extend over the propylitic and carbonatization stages, mostly with chalcopyrite as part of the calcite-chlorite-epidote-hematite infill assemblage. The hydrothermal history of the Cristalino deposit ended with a discrete precipitation of K-feldspar in veins, characterizing a local and new potassic infill stage.

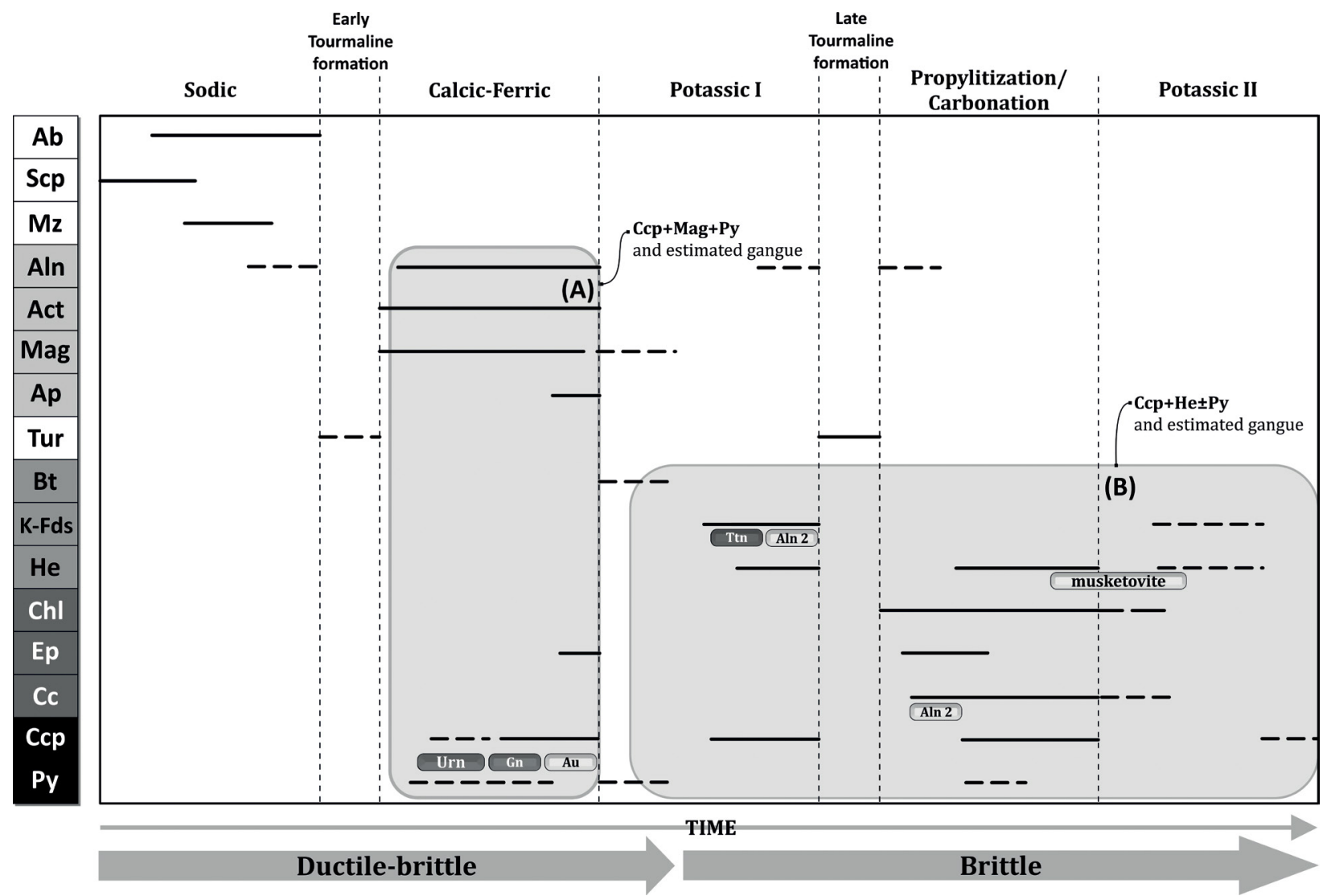

Ab: albite; Act: actinolite; Aln: allanite; Ap: apatite; Bt: biotite; Cc: calcite; Ccp: chalcopyrite; Chl: chlorite; Ep: epidote; Fds: K-feldspar; Gn: galena; He: hematite; Mag: magnetite; Mz: monazite; Py: pyrite; Scp: scapolite; Tur: tourmaline; Urn: uraninite.

Figure 10. Paragenetic sequence of the hydrothermal alteration at the Cristalino deposit. (A) First mineralizing stage marked by a chalcopyrite + magnetite + pyrite \pm uraninite \pm galena $\pm \mathrm{Au}$ assemblage spatially associated with $\mathrm{Ca}-\mathrm{Fe}$ alteration zones; (B) second mineralizing stage with chalcopyrite-hematite \pm pyrite associated in part with potassic alteration and epidote-calcite-chlorite alteration. 
The chalcopyrite-pyrite-magnetite and the chalcopyrite-hematite ore parageneses reflect distinct oxidation state of the mineralizing fluid, but also availability of iron. The magnetite formed plentifully during the calcic-ferric alteration, but was inexpressive in the subsequent alterations, when hematite became the major iron oxide without being, nonetheless, abundant.

The differences regarding ore associations, redox conditions and $\mathrm{Cu} / \mathrm{Fe}$ ratios of the fluid, and the crustal levels where the mineralization took place are suggestive that two IOCG systems may be superimposed at Cristalino. At a greater depth, sulfides (chalcopyrite, pyrite, with minor millerite and galena) alongside magnetite, monazite, allanite and minor apatite and uraninite, initially precipitated during the calcic-ferric alteration, whereas the younger sulfide generation, chiefly represented by chalcopyrite-rich breccias and veins, precipitated mainly during the potassic alteration, when rocks had been significantly exhumed.

The $\log f_{\mathrm{O} 2}$ vs. $\log a_{\Sigma S}$ diagram, at $2 \mathrm{kbar}$ and $350^{\circ} \mathrm{C}$, depicted in Figure 11, summarizes possible conditions of the mineralization stages in the Cristalino deposit.

A few multistage IOCG deposits have been described in the Carajás Province in the last decade and they seem to be confined to the southern sector of the $\mathrm{CD}$. The first mineralization stage of the Cristalino deposit is comparable to those

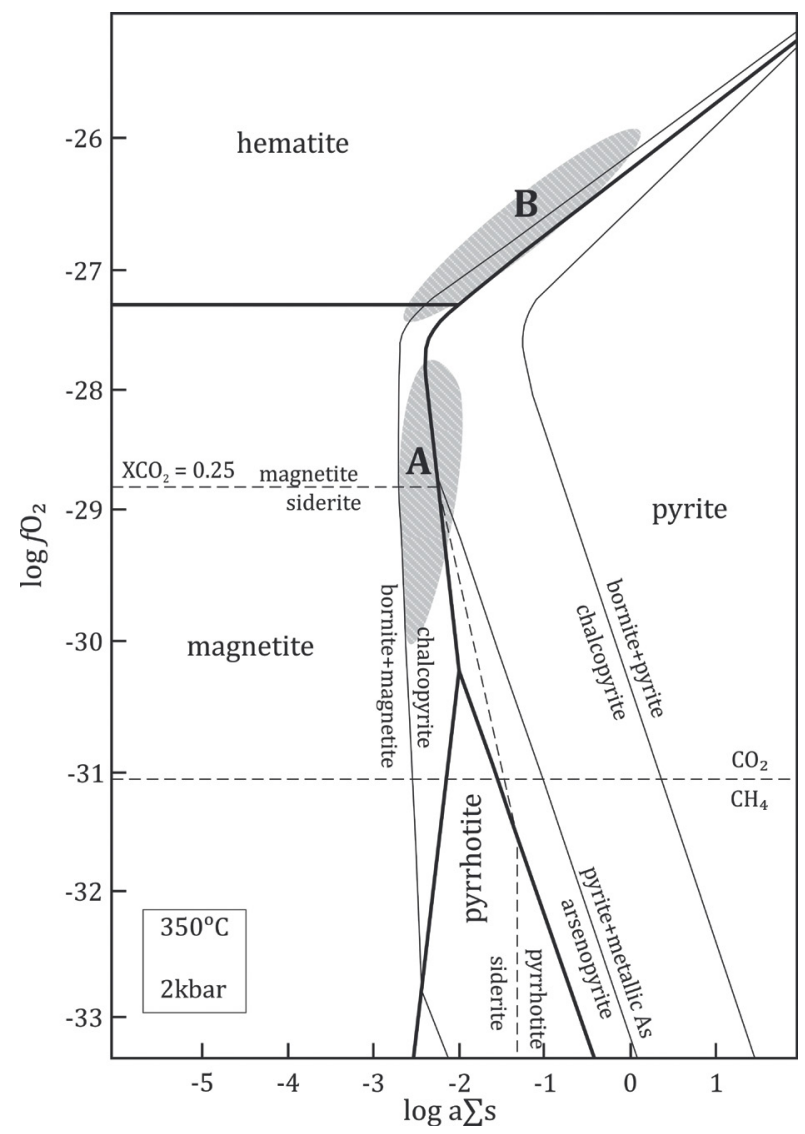

Figure 11. $\log \mathrm{a}_{\Sigma \mathrm{S}}-\log f \mathrm{O}_{2}$ diagram at $350^{\circ} \mathrm{C}$ and $2 \mathrm{kbar}$ (modified from Mikucki \& Ridley 1993). (A) Suggested conditions for the first mineralization stage, with formation of chalcopyrite, pyrite and magnetite at relatively lower oxygen fugacity $\left(\mathrm{fO}_{2}\right)$ and sulfur activity $\left(a_{\mathrm{S}_{2}}\right)$. (B) Suggested conditions for the second mineralization stage, at higher $\mathrm{fO}_{2}$ and $\mathrm{a}_{\mathrm{S} 2}$, allowing the formation of chalcopyrite-hematite with minor pyrite and practically no magnetite. of the Neoarchean Sossego (Sequerinho orebody), Bacaba, Visconde, and Castanha IOCG systems (Monteiro et al. 2008, Moreto et al. 2015a, 2015b, Silva et al. 2015, Xavier et al. 2017). The $\mathrm{Pb}-\mathrm{Pb}$ age of $2,719 \pm 36 \mathrm{Ma}$ obtained on sulfides of a chalcopyrite-magnetite breccia from the Cristalino deposit (Soares et al. 2001) supports its formation in Neoarchean times, despite the high uncertainties of the analytical method used. On the other hand, the second mineralization stage is comparable to the Paleoproterozoic IOCG systems that have been described at the Sossego (Sossego orebody) and Alvo 118 deposits.

The neighboring Borrachudo IOCG deposit also presents two mineralization stages (Previato 2016). The first copper mineralization was incipient and assumed to be Neoarchean. It consists of chalcopyrite-magnetite ore with abundant apatite formed in a brittle-ductile deformational environment. The second and most economic copper mineralization, dated at 2.01 Ga (U-Pb in titanite, Previato 2016), is composed mainly of chalcopyrite (up to $90 \%$ ) and associated with low-temperature minerals (chlorite, epidote, calcite). Magnetite is scarce. The proximity and similarities between the mineralization stages of both Cristalino and Borrachudo deposits suggest that they might be co-genetic and part of the E-W corridor of Neoarchean IOCG systems in Carajás.

\section{CONCLUSIONS}

The Cruzadāo Granite is for the time first described in the Cristalino deposit and is the oldest unit that occurs there. Host rocks of the deposit are mainly bimodal volcanic rocks of the Parauapebas Formation that have been subjected to an early and regional sodic alteration and locally deformed by shear zones. It was followed by pervasive calcic-ferric, potassic I, and propylitic alterations. The propylitic type grades to carbonatization, which is represented by an array of calcite-rich veins. The hydrothermal history in the Cristalino area ends with a new but discrete potassic alteration (II). These metasomatic processes affected rocks subjected to deformational regimes that evolved from ductile-brittle to brittle, the transition occurring between the calcic-ferric and the potassic alteration I.

The Cristalino deposit is characterized by a major $\sim \mathrm{N} 15^{\circ} \mathrm{W}$ trending ore body that resulted from two mineralizing stages. The earlier stage took place at a greater depth and produced an ore association composed of chalcopyrite, pyrite, and magnetite, minor monazite and allanite, and subordinate amounts of uraninite, millerite, galena, and gold, yielding a $\mathrm{Cu}-\mathrm{Fe}-\mathrm{Ni}-\mathrm{Au}-\mathrm{U}-\mathrm{Pb}-\mathrm{REE}$ signature. Sulfides precipitated initially as disseminations and then in breccia matrix and veins, particularly in Ca-Fe altered rocks. The later stage occurred at a shallower crustal level, where a practically magnetite-free ore association, consisting essentially of chalcopyrite \pm hematite \pm pyrite, was formed. The main modes of occurrence are in breccias and veins generated during the potassic and succeeding alterations. These ore associations are indicative that the hydrothermal system evolved with temperature decrease and increase in $\mathrm{fO}_{2}$, and $\mathrm{Cu} / \mathrm{Fe}$ ratio. However, $\mathrm{fO} 2$ decreased locally to give rise to musketovite. 
By comparison with similar Carajás copper-gold deposits, the first mineralization stage would be equivalent to the Neoarchean Sossego (Sequeirinho orebody), Castanha, Bacaba, Visconde deposits. The 2,719 $\pm 36 \mathrm{Ma}(\mathrm{Pb}-\mathrm{Pb}$ in sulfide) age determined for the magnetite-rich ore in the Cristalino deposit supports this interpretation. The second mineralization stage, with chalcopyrite-rich and hematite-bearing ore in breccias is comparable to the Paleoproterozoic Alvo 118 and Sossego (Sossego-Curral orebody) deposits. Cristalino would be then another example of a multi-stage deposit lying in the E-W corridor of Neoarchean IOCG systems in Carajás.

\section{ACKNOWLEDGEMENTS}

The authors thank the Graduate Program of Geology and Geochemistry (PPGG) of UFPA, the National Council for Scientific and Technological Development $(\mathrm{CNPq})$ for the scholarship granted to GSC, the Vale Mining Company, particularly geologists Cleive Ribeiro, Benevides Aires and Fabrício Franco for their support and field activities in the Carajás region, Prof. Dr. Claudio Nery Lamarão and geologist/technician Ms. Gisele Marques from the Microanalysis Laboratory of the IG-UFPA, and the Geosciences Institute of Amazon — Geociam (INCT Program - CNPq/MCT-Fapespa 573733/2008-2).

\section{ARTICLE INFORMATION}

Manuscript ID: 20180015. Received on: 02/18/2018. Approved on: 12/28/2018.

G.S.C. wrote the first draft of the manuscript and prepared all the Figures. R.P.X. and R.N.N.V. provided advisorship regarding hydrothermal alteration, IOCG deposits and Carajás domain geology, revised and improved the manuscript and figures through corrections and suggestions. Competing interests: The authors declare no competing interests.

\section{REFERENCES}

Araújo O.J.B. \& Maia R.G.N. 1991. Serra dos Carajás: folha SB.22-Z-A. Estado do Pará. Escala 1:250.000. Texto explicativo. Brasília: DNPM/ CPRM.164 p. il. Programa Levantamentos Geológicos Básicos do Brasil (PLGB).

Araújo O.J.B., Maia R.G.N., Jorge-João X.S., Costa J.B.S. 1988. A megaestruturação da folha Serra dos Carajás. In: Congresso Latino Americano de Geologia, 7. Anais... p. 324-333.

Barros C.E.M., Barbey P., Boullier A.M. 2001. Role of magma pressure, tectonic stress and crystallization progress in the emplacement of the syntectonic granites. The A-type Estrela Granite Complex (Carajás Mineral Province, Brazil). Tectonophysics, 343(1):93-109. http://dx.doi. org/10.1016/S0040-1951(01)00260-8

Barros C.E.M., Sardinha A.S., Barbosa J.P.O., Macambira M.J.B., Barbey P., Boullier A.M. 2009. Structure, petrology, geochemistry and zircon U/ $\mathrm{Pb}$ and $\mathrm{Pb} / \mathrm{Pb}$ geochronology of the syn-kinematic Archean $(2.7 \mathrm{Ga})$ A-type granites from the Carajás Metallogenic Province, northern Brazil. Canadian Mineralogist, 47(6):1423-1440. https://doi.org/10.3749/ canmin.47.6.1423

Costa J.B.S., Araújo O.J.B., Santos A., Jorge João X.S., Macambira M.J.B., Lafon J.M. 1995. A Província Mineral de Carajás: aspectos tectonoestruturais, estratigráficos e geocronológicos. Boletim do Museu Paraense Emílio Goeldi, 7:199-235.

Craveiro G.S., Xavier R.P., Villas R.N.N. 2018. Mineral chemistry and geothermometry of alteration zones in the IOCG Cristalino Deposit, Carajás Mineral Province, Brazil. in press.

Dall'Agnol R., Oliveira D., Guimarães F.V., Gabriel E.O., Feio G.R.L., Lamarão C.N., Althoff F.J., Santos P.A., Teixeira M.F.B, Silva A.C., Rodrigues D.S., Santos M.J.P, Silva C.R.P., Santos R.D., Santos P.J.L. 2013. Geologia do Subdomínio de Transição do Domínio Carajás: Implicações para a evolução arqueana da Província Carajás - Pará. In: Simpósio Geologia da Amazônia, 13. Proceedings... Belém: SBG. 1 CD-ROM.

Dall’Agnol R., Teixeira N.P., Rämö O.T., Moura C.A.V., Macambira, M.J.B., Oliveira D.C. 2005. Petrogenesis of the Paleoproterozoic, rapakivi, A-type granites of the Archean Carajás Metallogenic Province, Brazil. Lithos, 80(1):101-129. http://dx.doi.org/10.1016/j.lithos.2004.03.058

Dias G.S., Macambira M.B., Dall’Agnol R., Soares A.D.V., Barros C.E.M. 1996. Datações de zircões de sill de metagabro: comprovação de idade arqueana da Formação Águas Claras, Carajás, Pará. In: Simpósio de Geologia da Amazônia, 5. Anais... Belém: Sociedade Brasileira de Geologia, p. 376-378.
Feio G.R.L., Dall'Agnol R., Dantas E.L., Macambira M.J.B., Santos J.O.S., Althoff F.J., Soares J.E.B. 2013. Archean granitoid magmatism in the Canaã dos Carajás área: Implications for crustal evolution of the Carajás Province, Amazonian craton, Brazil. Precambrian Research, 227:157-185. http:// dx.doi.org/10.1016/j.precamres.2012.04.007

Gibbs A.K., Wirth K.R., Hirata W.K., Olszewski Jr. W.J. 1986. Age and composition of the Grão Pará Group volcanics, Serra dos Carajás. Revista Brasileira de Geociências, 16(2):201-211.

Grainger C.J., Groves D.I., Tallarico F.H.B., Fletcher I.R. 2008. Metallogenesis of the Carajás Mineral Province, southern Amazon Craton: Varying styles of Archean through Paleoproterozoic to Neoproterozoic base- and precious-metal mineralization. Ore Geology Reviews, 33(3-4):451-489. http://dx.doi.org/10.1016/j. oregeorev.2006.10.010

Huhn S.R.B., Souza C.I.J., Albuquerque M.C., Leal E.D., Brustolin V. 1999. Descoberta do depósito $\mathrm{Cu}$ ( $\mathrm{Au}$ ) Cristalino: Geologia e mineralização associada região da Serra do Rabo - Carajás - PA. In: Simpósio de Geologia da Amazônia, 6. Proceedings... Manaus: SBG/NO, p. 140-143.

Hunger R.B. 2017. O depósito de óxido de ferro cobre-ouro (IOCG) Grota Funda, Domínio Carajás (PA): alteração hidrotermal, regime de fluidos e idade da mineralização. MS Dissertation, Universidade Estadual de Campinas, Campinas, $182 \mathrm{p}$.

Lindenmayer Z.G., Fleck A., Gomes C.H., Santos A.B.S., Caron R., Paula F.C., Laux J.H., Pimentel M.M., Sardinha A.S. 2005. Caracterização geológica do alvo estrela (Cu-Au), Serra dos Carajás, Pará. In: Marini J.O., Queiróz E.T., Ramos W.B. (Eds.), Caracterização de Depósitos Minerais em Distritos Mineiros da Amazônia. Brasília: DNPM, CT-Mineral / FINEP, ADIMB, p. 137-205.

Lindenmayer Z.G., Laux J.H., Teixeira J.B.G. 2001. Considerações sobre a origem das Formações Ferríferas da Formação Carajás, Serra dos Carajás. Revista Brasileira de Geociências, 31(1):21-28.

Lobato L.M., Rosière C.A., Silva R.C.F., Zucchetti M., Baars F.J., Seoane J.C.S., Rios F.J., Pimentel M., Mendes G.E., Monteiro A.M. 2005. A mineralização hidrotermal de ferro da Província Mineral de Carajás controle estrutural e contexto na evolução metalogenética da Província. In: Marini J.O., Queiróz E.T., Ramos W.B. (Eds.), Caracterização de depósitos minerais em distritos mineiros da Amazônia. Brasília: DNPM-CT/MineralADIMB, p. 25-92. 
Macambira E.M.B.,Vale A.G. 1997. Programa Levantamentos Geológicos Básicos do Brasil: São Felix do Xingu, Folha SB.22-Y-B. Estado do Pará. Brasília: Departamento Nacional de Produção Mineral-Companhia de Pesquisa de Recursos Minerais (DNPM/CPRM), 384 p.

Macambira J.B. 2003. O ambiente deposicional da Formação Carajás e uma proposta de modelo evolutivo para a Bacia Grão Pará. Doctoral Thesis, Universidade Estadual de Campinas, Campinas, 217 p.

Machado N., Lindenmayer Z.G., Krogh T.E., Lindenmayer D. 1991. U-Pb geochronology of Archean magmatism and basement reactivation in the Carajás area, Amazon shield, Brazil. Precambrian Research, 49(3-4):329354. https://doi.org/10.1016/0301-9268(91)90040-H

Mansur E.T., Ferreira Filho C.F. 2016. Magmatic structure and geochemistry of the Luanga mafic-ultramafic complex: Further constraints for the PGEmineralized magmatism in Carajás, Brazil. Lithos, 266-267:28-43. http:// dx.doi.org/10.1016/j.lithos.2016.09.036

Meirelles M.R., Dardenne M.A. 1991. Vulcanismo basáltico de afinidade shoshonítica em ambiente de arco arqueano, Grupo Grão Pará, Serra dos Carajás, PA. Revista Brasileira de Geociências, 21(1):41-50.

Melo G.H.C., Monteiro L.V.S., Xavier R.P., Moreto C.P.N., Santiago E.S.B., Dufrane S.A., Aires B., Santos A.F.F. 2017. Temporal Evolution of the giant Salobo IOCG deposit, Carajás Province (Brazil): constraints from paragenesis of hydrothermal alteration and U-Pb geochronology. Mineralium Deposita, 52(5):709-732. https://doi.org/10.1007/s00126-016-0693-5

Mikucki E.J \& Ridley J.R. 1993. The hydrothermal fluid of Archean lodegold deposits at different metamorphic grades: composition constrains from ore and wallrock alteration assemblages. Mineralium Deposita, 28(6):469481. http://dx.doi.org/10.1007/BF02431603

Monteiro L.V.S., Xavier R.P., Carvalho E.R., Hitzman M.W., Johnson C.A., Souza Filho C.R., Torresi I. 2008. Spatial and temporal zoning of hydrothermal alteration and mineralization in the Sossego iron oxidecopper-gold deposit, Carajás Mineral Province, Brazil: Parageneses and stable isotope constraints. Mineralium Deposita, 43(2):129-159. https:// doi.org/10.1007/s00126-006-0121-3

Moreto C.P.N., Monteiro L.V.S., Xavier R.P., Creaser R.A., Dufrane S.A., Melo G.H.C., Delinardo Silva M.A., Tassinari C.C.G., Sato K. 2015a. Timing of multiple hydrothermal events in the iron oxide-copper-gold deposits of the Southern Copper Belt, Carajás Province, Brazil. Mineralium Deposita, 50(5):517-546. https://doi.org/10.1007/s00126-014-0549-9

Moreto C.P.N., Monteiro L.V.S., Xavier R.P., Creaser R.A., Dufrane S.A., Tassinari C.C.G., Sato K., Kemp A.I.S., Amaral W.S. 2015b. Neoarchean and Paleoproterozoic iron oxide-copper-gold events at the Sossego deposit, Carajás Province, Brazil, Re-Os and U-Pb geochronological evidence. Economic Geology, 110(3):809-835. https://doi.org/10.2113/ econgeo.110.3.809

Mougeot R., Respaut J.P., Briqueu L., Ledru P., Milesi J.P., Lerouge C., Marcoux E., Huhn S.B., Macambira M.J.B. 1996. Isotope geochemistry constrains for $\mathrm{Cu}, \mathrm{Au}$ mineralizations and evolution of the Carajás Province (Para, Brazil). In: Congresso Brasileiro de Geologia 39. Proceedings... Salvador: SBG, p. 321-324.

Nogueira A.C.R., Truckenbrodt W., Pinheiro R.V.L. 1995. Formação Águas Claras, Pré-cambriano da Serra dos Carajás: redescrição e redefinição litoestratigráfica. Boletim do Museu Paraense Emílio Geoldi, 7:177-197.

Oliveira J.R. 1994. Programa Levantamentos Geológicos Básicos do Brasil: Folha Serra Pelada (Folha SB.22-Z-A). Estado do Pará. Brasília: DNPM/ CPRM, 248 p.

Pinheiro R.V.L. \& Holdsworth R.E. 2000. Evolução tectonoestratigráfica dos sistemas transcorrentes Carajás e Cinzento, Cinturão Itacaiúnas, na borda leste do Cráton Amazônico, Pará. Revista Brasileira de Geociências, 30(4):597-606

Pinto A. 2012. Salobo Copper Mine Feasibility in Carajás, Pará State. In: Brazilian Symposium on Mineral Exploration, 5. Oral presentation. Ouro Preto.

Previato M. 2016. Evolução paragenética e regime de fluidos hidrotermais no sistema Borrachudo: Implicações para a metalogênese e cobre na Província Carajás. MS Dissertation, Universidade de São Paulo, São Paulo, 131 p.

Rämö O.T., Dall’Agnol R., Macambira M.J.B., Leite A.A.S., Oliveira D.C. 2002. 1.88 Ga Oxidized A-type Granites of the Rio Maria Region, Eastern Amazonian Craton, Brazil: Positively Anorogenic! The Journal of Geology, 110 (5):603-610. http://dx.doi.org/10.1086/341761
Réquia K., Stein H., Fontboté L., Chiaradia M. 2003. Re-Os and $\mathrm{Pb}-\mathrm{Pb}$ geochronology of the Archean Salobo iron oxide copper-gold deposit, Carajás Mineral Province, northern Brazil. Mineralium Deposita, 38(6):727738. http://dx.doi.org/10.1007/s00126-003-0364-1

Ribeiro A.A., Suita M.T.F., Sial A.N., Fallick A.E., Eli F., Goulard A.E. 2009. Geoquímica de isótopos estáveis $(\mathrm{C}, \mathrm{S}$ e $\mathrm{O}$ ) das rochas encaixantes e do minério de $\mathrm{Cu}(\mathrm{Au})$ do depósito Cristalino, Província Mineral de Carajás, Pará. Geochimica Brasiliensis, 23(2):159-176. http://dx.doi.org/10.21715/ gb.v23i2.304

Rio Doce Geologia e Mineração (Docegeo) 1988. Revisão litoestratigráfica da Província Mineral de Carajás - Litoestratigrafia e principais depósitos minerais. In: Congresso Brasileiro de Geologia, 35. Expanded abstract.. Belém: SBG, p. 11-54.

Ronzê P.C., Soares A.D.V., Santos M.G.S. dos, Barreira C.F. 2000. Alemão copper-gold (U-REE) deposit, Carajás, Brazil, In: Porter T.M. (Ed.), Hydrothermal iron-oxide copper-gold and related deposits: a global perspective. Adelaide : PGC Publishing, p. 191-202.

Santos J.O.S., Hartmann L.A., Gaudette H.E., Groves D.I., Macnaughton N.J., Fletcher I.R. 2000. A new understanding of the Provinces of the Amazon Craton based of integration of field mapping and $\mathrm{U}-\mathrm{Pb}$ and $\mathrm{Sm}$ Nd geochronology. Gondwana Research, 3(4):453-488. http://dx.doi. org/10.1016/S1342-937X(05)70755-3

Santos M.G.S. 2002. Estudo dos isótopos de Pb e Nd do Depósito de $\mathrm{Cu}$-Au (U-ETR) Alemão, Província Mineral de Carajás (PA). MS Dissertation, Universidade Federal do Pará, Belém, 126 p.

Sardinha A.S., Barros C.E.M., Krymsky R. 2006. Geology, geochemistry and $\mathrm{U}-\mathrm{Pb}$ geochronology of the Archean (2.74 Ga) Serra do Rabo granite stocks, Carajás Metallogenic Province, northern Brazil. Journal of South American Earth Sciences, 20(4):327-339. http://dx.doi.org/10.1016/j. jsames.2005.11.001

Siepierski L. 2016. Geologia, petrologia e potencial para mineralizações magmáticas dos corpos máfico-ultramáficos da região de Canaã dos Carajás, Província Mineral de Carajás. Doctoral Thesis, Universidade de Brasília, Brasília, $158 \mathrm{p}$

Silva A.R., Villas R.N., Lafon J., Craveiro G.S., Ferreira V.P. 2015. Stable isotope systematics and fluid inclusion studies in the Cu-An Visconde deposit, Carajás Mineral Province, Brazil: implications for fluid source generation. Mineralium Deposita, 50(5):547-569. http://dx.doi. org/10.1007/s00126-014-0558-8

Soares A.D.V., Macambira M.J.B., Santos M.G.S., Vieira E.A., Masotti F.S. Souza C.I.J., Padilha J.L., Magni M.C.V.2001. Depósito Cu (Au) Cristalino, Serra dos Carajás PA: Idade da Mineralização com base em Análises Pv-Pb em sulfetos (Dados Preliminares). In: Simpósio de Geologia da Amazônia, 7. Proceedings... Belém: SBG. 1 CD-ROM.

Soares A.D.V., Ronzê P.C., Santos M.G.S., Leal E.D., Barreira C.F. 1999. Geologia e mineralizações do depósito de $\mathrm{Cu}-\mathrm{Au}$ Alemão - Província Mineral de Carajás (PA). In: Simpósio de Geologia da Amazônia, 6. Proceedings... Manaus: SBG, p. 144-147.

Tallarico F.H.B. 2003. O cinturão cupro-aurífero de Carajás, Brasil. Doctoral Thesis, Universidade Estadual de Campinas, Campinas, 229 p.

Tallarico F.H.B., Figueiredo B.R., Groves D.I., Kositcin N., McNaughton N.J., Fletcher I.R., Rego J.L. 2005. Geology and SHRIMP U-Pb geochronology of the Igarapé Bahia deposit, Carajás copper-gold belt, Brazil: an Archean $(2.57 \mathrm{Ga})$ example of iron-oxide $\mathrm{Cu}-\mathrm{Au}-(\mathrm{U}-$ REE) mineralization. Economic Geology, 100(1):7-28. https://doi. org/10.2113/100.1.0007

Tavares F.M. 2015. Evolução geotectônica do nordeste da Província Carajás. Doctoral Thesis, Universidade Federal do Rio de Janeiro, Rio de Janeiro, $115 \mathrm{p}$.

Teixeira A.S., Ferreira Filho C.F., Giustina M.E.S.D., Araújo S.M., Silva H.H.A.B. 2015. Geology, petrology and geochronology of the Lago Grande layered complex: evidence for a PGE-mineralized magmatic suite in the Carajás Mineral Province, Brazil. Journal of South American Earth Sciences, 64(1):116-138. http://dx.doi.org/10.1016/j. jsames.2015.09.006

Teixeira J.B.G. 1994. Geochemistry, petrology, and tectonic setting of Archean basaltic and dioritic rocks from the N4 Iron deposit, Serra dos Carajás, Pará, Brazil. Doctoral Thesis, Universidade de São Paulo, São Paulo, $161 \mathrm{p}$. 
Torresi I., Xavier R.P., Bortholoto D.F.A., Monteiro L.V.S. 2012. Hydrothermal alteration, fluid inclusions and stable isotope systematics of the Alvo 118 iron oxide-copper-gold deposit, Carajás Mineral Province (Brazil); Implications for ore genesis. Mineralium Deposita, 47(3):299-323. http://dx.doi.org/10.1007/ s00126-011-0373-4

Trendall A.F., Basei M.A.S., De Laeter J.R., Nelson D.R. 1998. SHRIMP $\mathrm{U}-\mathrm{Pb}$ constraints on the age of the Carajás formation, Grão Pará Group, Amazon Craton. Journal of South American Earth Sciences, 11(3):265-277. http://dx.doi.org/10.1016/S0895-9811(98)00015-7

Vale. Projeto Cristalino, Mapa geológico do Alvo Cristalino Sul. Scale: 1:5.000, 2003.

Vasquez L.V., Rosa-Costa L.R., Silva C.G., Ricci P.F., Barbosa J.O., Klein E.L., Lopes E.S., Macambira E.B., Chaves C.L., Carvalho J.M., Oliveira J.G., Anjos G.C., Silva H.R. 2008. Geologia e Recursos Minerais do Estado do Pará: Sistema de Informações Geográficas-SIG: Texto Explicativo dos Mapas Geológico e Tectônico e de Recursos Minerais do Estado do Pará. Scale 1:1.000.000. Belém: CPRM.
Wirth K.R., Gibbs A.K., Olszewski W.J. 1986. U-Pb ages of zircons from the Grão Pará group and Serra dos Carajás granite, Pará, Brazil. Revista Brasileira de Geociências, 16(2):195-200.

Xavier R.P., Monteiro L.V.S., Moreto C.P.N., Pestilho A.L.S., Melo G.H.C., Silva M.A.D., Aires B., Ribeiro C., Silva F.H.F. 2012. The iron oxide coppergold system of the Carajás Mineral Province, Brazil. In: Hedenquist J.W., Harris M., Camus F. (Eds.), Geology and Genesis of Major Copper Deposits and Districts of the World: A Tribute to Richard H. Sillitoe. Society of Economic Geologists, 16, Chapter X. https://doi.org/10.5382/SP.16.17

Xavier R.P., Moreto C.P.N., Melo G.H.C., Toledo P., Hunger R., Delinardo M., Faustinoni J., Lopes A. 2017. Geology and metallogeny of Neoarchean and Paleoproterozoic copper systems of the Carajás Domain, Amazonian Craton, Brazil. In: Biennial SGA Meeting of the Society for Geology Applied to Mineral Deposits, 14. Proceedings... Quebec, p. 899-902.

Xavier R.P., Wiedenbeck M., Trumbull R.B., Dreher A.M., Monteiro L.V.S., Rhede D., Araújo, C.E.G., Torresi I. 2008. Tourmaline B-isotopes fingerprint marine evaporites as the source of high-salinity ore fluids in iron-oxide-coppergold deposits, Carajás Mineral Province (Brazil). Geology, 36:743-746. 